\title{
Temporal evolution of surface humidity in Spain: recent trends and possible physical mechanisms
}

\author{
Sergio M. Vicente-Serrano ${ }^{1}$, Cesar Azorin-Molina ${ }^{1}$, Arturo Sanchez-Lorenzo ${ }^{2}$, Enrique Morán- \\ Tejeda $^{3}$, Jorge Lorenzo-Lacruz ${ }^{1}$, Jesús Revuelto ${ }^{1}$, Juan I. López-Moreno ${ }^{1}$, Francisco Espejo ${ }^{4}$ \\ ${ }^{1}$ Instituto Pirenaico de Ecología, Consejo Superior de Investigaciones Científicas (IPE-CSIC), \\ Campus de Aula Dei, P.O. Box 13034, E-50059, Zaragoza, Spain \\ ${ }^{2}$ Department of Physics, University of Girona, Girona, Spain \\ ${ }^{3}$ University of Geneva, Switzerland \\ ${ }^{4}$ Agencia Estatal de Meteorologia (AEMET), Spain \\ * Corresponding author: svicen@ipe.csic.es
}

Abstract: We analyzed the evolution of surface relative humidity (RH) and specific humidity (q) in Spain, based on complete records available from the State Meteorological Agency of Spain. The surface RH records used span the period 1920-2011, but because of spatial and temporal constraints in the dataset we used a subset of the data, covering the period 1961-2011. The subset contained 50 monthly series of $\mathrm{RH}$, which were created through a process of quality control, reconstruction and homogenization. The data shows that there was a large decrease in $\mathrm{RH}$ over mainland Spain from 1961 to 2011, which was greatest in spring and summer. In contrast, there was no overall change in the specific humidity in this period, except in spring, when an increase was observed. The decrease in RH affected the entire country, but the changes in specific humidity were less homogeneous. For specific humidity there was a general increase in the northern and eastern parts of Spain, whereas negative trends dominated in the central and southern areas, mainly during the summer months. The results suggest that an increase in the water holding capacity of the atmosphere as a consequence of warming during recent decades has not been accompanied by an increase in the surface water vapor content, because the supply of water vapor from the main terrestrial and oceanic areas has been constrained. We discuss the implications of these findings for evapotranspiration processes, precipitation and water management in Spain. 
Key-words: global warming, climate change, water vapor, relative humidity, specific humidity, evapotranspiration, drought

\section{Introduction}

Water vapor is one of the most important greenhouse gasses, and exceeds $\mathrm{CO}_{2}$ by several times in terms of its greenhouse contribution (Trenberth et al., 2007). It affects other climate elements via absorption of radiation and through the formation and evolution of clouds. The release of latent heat as a consequence of water vapor condensation has a major impact on the atmospheric circulation system and the transport of heat from tropical to temperate and cold regions (Gimeno et al., 2010). Relative humidity $(\mathrm{RH})$ also plays a substantial role in the formation of aerosols, which are formed (among various mechanisms) in the atmosphere through nucleation of gas phase species (Zhang et al., 2012). This process is highly dependent on the levels of RH, as new particle formation takes place preferentially at low RH (e.g. Hamed et al., 2011).

Atmospheric water vapor is also a very important component of the water cycle because water vapor in the lower troposphere is the main source of water for precipitation in all weather systems. For extratropical cyclones, Trenberth (1999) estimated that an average of approximately $70 \%$ of the precipitation comes from moisture that was already in the atmosphere at the time the storm formed.

The quantity of water vapor that can be held in a volume of air is defined by the Clausius-Clapeyron (C-C) relationship, whereby the amount of water vapor increases exponentially with increasing temperature (Allan, 2012). Evidence for global warming has increased during the last five decades (Hansen et al., 2010; Jones et al., 2012), and various global scale studies have shown a marked increase in the specific humidity $(q)$, whereas RH has remained constant or decreased slightly (Santer et al., 2007; Trenberth et al., 2005; Dai, 2006). In general, studies considering short and recent time periods (from the 1970s to the 1990s) have shown increases in water vapor, whereas those considering longer periods (from prior to 1960 to the present) have shown mixed results (Seidel et al., 2007). Based on a quality controlled and homogenized global gridded dataset for the 
period 1973 to 2003, Willett et al. (2008) found that trends for RH were mostly not significant over the land, giving support to the theory of constant RH over large spatial and temporal scales under global warming conditions. These findings are consistent with projections of increased average precipitation and extreme events under a warmer climate, as a consequence of an increase in the availability of water in the atmospheric column (Meehl et al., 2007). Nevertheless, Simmons et al. (2010) used a recently updated observational dataset and Reanalysis data to show that a widespread reduction in $\mathrm{RH}$ occurred over terrestrial areas during the last decade. The study showed a net drying (both $q$ and $\mathrm{RH}$ ) in areas including the western United States, South America and Europe, and has triggered a debate on how surface humidity might be reacting to global warming processes; it also highlighted the importance of undertaking studies based on high quality observational datasets.

Regional studies in North America (e.g. Gaffen and Ross, 1999; Seidel et al., 2007; Brown and DeGaetano, 2012; Van WignGaarden and Vincent, 2005) have shown a general decrease in RH in recent decades. This has been confirmed recently by Isaac and Van WignGaarden (2012), who used an updated analysis covering the period $1948-2010$ to demonstrate a reduction of $0.5 \%$ decade $^{-1}$ in $\mathrm{RH}$, coupled with an increase in $q$ of approximately $0.04 \mathrm{~g} \mathrm{~kg}^{-1}$ decade $^{-1}$. A similar reduction in $\mathrm{RH}$ has been reported in subregional studies of Europe, including in Poland (Wypych, 2010), the Czech Republic (Cahinova and Huth, 2009; Brazdil et al., 2009), Northern Ireland (Buttler and GarcíaSuárez, 2012), the Alpine region (Brunetti et al., 2009) and southern Spain (Espadafor et al., 2011). These studies have typically involved analysis of data (sometimes not quality controlled) from few stations, and have been focused on small areas. Thus, how atmospheric humidity is reacting to global warming processes remains unclear, and this situation highlights the importance for research based on high quality observational datasets.

The southern Europe/Mediterranean region is one of the most important areas in the world in relation to the impact of climate change processes, because it has a characteristic transitional climate that results in high spatial and temporal variability in precipitation. This variability has been 
reported in numerous studies during recent decades (Xoplaki et al., 2004; Norrant and Douguedroit, 2006), and there is a high level of uncertainty about future changes in precipitation (Giorgi and Lionello, 2008). However, there is general agreement on future scenarios of increased temperature during the 21 st century (Solomon et al., 2007). Thus, given the implications of atmospheric humidity for the hydrological cycle, including evapotranspiration (Allen et al., 1998; Liu and McVicar, 2012), water availability, forest fire propagation (Flannigan and Harrington, 1997) and the severity of drought events (Hoerling et al., 2012), studies of this atmospheric parameter are needed because of the low level of knowledge of: (i) the behavior of atmospheric water vapor; and (ii) how atmospheric water vapor is affected by warming processes.

In this study we analyzed the evolution of surface humidity in Spain over recent decades using quality controlled and homogenized records, based on historical information collected by the State Meteorological Agency of Spain (AEMET). The objectives were to develop the highest quality database of RH and $q$ for Spain, and to analyze the behavior of these factors in mainland Spain, in the context of the evolution of the main sources of water vapor and variations in atmospheric water holding capacity produced by temperature changes. We provide evidence potentially supporting hypotheses on physical mechanisms that could drive the observed changes.

\section{Methods}

\subsection{Relative humidity measurements}

$\mathrm{RH}$ is defined as the ratio in percentage of the observed vapor pressure to the saturation vapor pressure with respect to water at the same temperature and pressure (WMO, 2008). AEMET climatological records for this atmospheric variable are measured using a standard psychrometer, which is a meteorological device comprising a wet bulb thermometer wrapped in an absorbent material (such as thin muslin soaked in distilled water or ice) and a dry bulb thermometer directly exposed to the air (Wexler, 1965). Air temperature is measured simultaneously by each thermometer, and the difference between the temperatures is recorded. To compute the $\mathrm{RH}$ the 
difference and the ambient temperature displayed by the dry bulb thermometer are used. Standard psychrometers are housed inside Stevenson screens to protect the instruments from direct solar radiation, precipitation, wind and atmospheric pollutants, and also to ensure natural ventilation. Accurate measurements of $\mathrm{RH}$ are difficult to achieve and mostly depend on the quality of the liquid-in-glass thermometer, and the operation and maintenance of the psychrometers. Although few metadata are available, AEMET ensures that the thermometer pairs used for RH measurements are accurately calibrated in air and are handled with care, and the measurements based on the wetdry method have remained stable for years.

\subsection{Dataset creation}

We obtained the complete dataset of monthly average RH from AEMET, consisting of data from 868 measurement stations covering the entire Spanish territory excluding the Canary Islands. The original monthly relative humidity and temperature series supplied by the AEMET are obtained from daily mean data averaged from standard observations at 00, 07, 13 and 18 UTC. For mean daily relative humidity and temperature measurements, corresponding monthly mean values are only computed for days with 3 or more observations and for those months having at least 26 days of observations, respectively: if not the whole day or month is excluded and set as missing.

The spatial density of the series is very high (Fig. 1), but the majority of stations have data for very few years. Figure 2A shows the number of stations having data for each month between January 1920 (1 station) and December 2011 (656 stations). Prior to 1960 there was a slow but progressive increase in the number of stations, but in 1961 there was a large increase, from 40 stations in December 1960 to 88 in January 1961. After 1961 the number of stations increased slowly until 2006, during which time almost 100 additional psychrometers were installed. In 2007 the number of measurements again increased with the installation of new hygrometers in automatic weather stations. The current number of stations measuring RH is approximately 600. This temporal evolution partly explains why the majority of the available series are of very short duration, and 
very few have 30 or more years of data (Fig. 2B). We ensured that all the stations chosen for the study used standard psychrometers for the entire time series.

To create a reliable dataset for analyzing the surface humidity trends in Spain, we initially separated the total recorded series into two subsets: the first contained series from stations that had $>25$ years of records (candidate stations), and the second contained series from stations that had $<25$ years of data and were located $<15 \mathrm{~km}$ from those stations in the first subset.

As a first step we applied a linear regression approach to add the data from the second subset to the nearest candidate stations for a common period of at least five years between the two series. In cases where the candidate and neighboring stations had no common period, data were directly assigned to the candidate series. The result of the reconstruction process was a set of 93 series. Given that there were few series available prior to 1961 (Fig. 2C), we selected the period 19612011 for the analysis, and chose those series having < $15 \%$ of monthly gaps during the period: 52 series fulfilled this criterion. The resulting 52 series were quality controlled to identify anomalous or questionable records in the series. For this purpose we followed the procedure based on comparison of the rank of each data record with the average rank of the data recorded in adjacent observatories (see Vicente-Serrano et al., 2010 for further details).

The approach followed in this study, which was based on reconstruction of the series by combining two or more original series, can result in inhomogeneities (Lanzante, 1996; Peterson et al., 1998). Inhomogeneities can also be introduced by changes in station location, alteration to the surrounding environment, observer changes and instrument replacement (Karl and Williams, 1987). Thus, to check and control the quality of the selected series, we analyzed the relative homogeneity using the Standard Normal Homogeneity Test (SNHT; Alexandersson, 1986). The creation of a reference series involved selection of the most correlated (first difference) series (Pearson $r>0.70$ ) from a minimum number of five stations (Peterson and Easterling, 1994). In the two cases where it was not possible to create a reference series following this criterion, the stations involved were removed from the final dataset. As a consequence of the length of some of the series it was possible that 
$181 e_{S}=6.112 e^{\frac{17.67 T}{T+243.5}}$,

182 where $\mathrm{T}$ is the monthly mean temperature.

\subsection{Calculation of specific humidity: $q$} expressions:

$q=\frac{1000 w}{1001+w}$

$w=\frac{R H \times w_{s}}{100}$, and

$w_{S}=\frac{0.622 e_{s}}{P_{S}-e_{s}}$, according to the equation:

The parameter $q$ is a measure of the mass of water vapor present in a given mass of air. To evaluate $q$ at each station we used the monthly series of surface pressure (hPa) and mean air temperature combined with the RH series (e.g. Dai, 2006; Willet et al., 2007). The pressure and mean temperature data were also quality controlled and tested for possible inhomogeneities following the procedure described above for RH. Based on Oort (1983), $q\left(\mathrm{~g} \mathrm{~kg}^{-1}\right)$ was calculated according to the

where $P_{s}$ is the surface air pressure $(\mathrm{hPa})$, and $e_{s}$ is the saturation vapor pressure (hPa) calculated 
Following Jones and Hulme (1996), from the homogeneous series of RH, $q$ and mean temperature a single regional series for mainland Spain was computed using the weighted averages of monthly records for each station. The weight factor was the ratio of the surface area represented by each station to the total area of Spain, based on Thiessen's polygon method.

\subsection{Additional datasets}

We used additional information to assess physical mechanisms potentially contributing to the evolution of atmospheric humidity from 1961 to 2011, including temperature, precipitation, sea surface temperature (SST) and soil moisture. Monthly precipitation series related to the 50 stations having quality controlled RH data for the period 1961 to 2011 were obtained from the MOPREDAS dataset, updated to 2011 (González-Hidalgo et al., 2011).

As the main source of surface humidity is related to the supply of moisture by the oceans (Gimeno et al., 2010), we assessed the influence of SST on surface humidity trends in Spain. For this purpose we used three datasets based on observation and satellite imagery: the Hadley Centre Sea Ice and Sea Surface Temperature dataset (HadISST; Rayner et al., 2003); the Extended Reconstructed Sea Surface Temperature (ERSST.v3b) dataset of the National Climatic Data Center of the NOAA (Smith et al., 2008); and the NOAA-AVHRR satellite-derived SST dataset at a spatial resolution of $1^{\circ}$ (Reynolds et al., 2002). We used three datasets to increase confidence in relation to the evolution of the SST in the regions that constitute the main sources of atmospheric humidity in the Iberian Peninsula (Gimeno et al., 2010b).

In addition to the ocean, an important source of humidity is evapotranspiration processes, as two thirds of precipitation over land areas returns to the atmosphere by this mechanism (Wang and Dickison, 2012). Evapotranspiration is determined by vegetation type and physiological mechanisms, but it is highly constrained by the availability of soil moisture (Jung et al., 2011), which is an important parameter determining the magnitude of water supply from the land to the atmosphere. As there are no reliable data on soil moisture for Spain covering the study period, we 
have used an indirect approximation to estimate this parameter. As a surrogate indicator we calculated a drought index, the Standardized Precipitation Evapotranspiration Index (SPEI; VicenteSerrano et al., 2010), which is based on a normalized climate balance model (precipitation minus potential evapotranspiration), and the reduction of precipitation and increase of PET can be considered as a plausible indicator of reduction in soil moisture. In a recent global study that compared drought indices, the SPEI was shown to best reproduce the temporal variability of soil moisture across various climate domains (Vicente-Serrano et al., 2012). The SPEI was obtained from the series of precipitation and potential evapotranspiration (PET), which was derived using the empirical Hargreaves's equation (Hargreaves and Samani, 1985).

\subsection{Data analysis}

Trends in the annual and seasonal series of $\mathrm{RH}$ and $q$ were calculated using the Kendall tau rank correlation coefficient (Kendall and Gibbons, 1990). This is more robust than parametric tests, and does not assume normality of the data series (Lanzante, 1996). Significant trends were defined as those below the threshold $p<0.05$. To identify the rates of change we used a regression analysis between the series of time (independent variable) and the series of $\mathrm{RH}$ and $q$ (dependent variable).

\section{Results and discussion}

\subsection{Temporal changes}

There was a large decrease in the RH in Spain between 1961 and 2011 (Fig. 4). At an annual scale, the decrease was $1 \%$ per decade, which implies a decrease of $5.1 \%$ during the analysis period. Although the same pattern was observed at a seasonal scale, there were differences in the magnitude of the change. Between 1961 and 2011, major decreases in RH occurred in summer (7.8\%) and spring $(5.1 \%)$, while smaller decreases were evident in winter and autumn $(3.3 \%$ and $4.2 \%$, respectively). The minimum values in the annual series were recorded in 2005 (60.3\%) and 2009 (60.2\%). This pattern is consistent with the global patterns reported by Simmons et al. (2010), who 
showed that an abrupt decrease in RH occurred over land areas in the last decade. In Europe, Buttler and García-Suárez (2012) showed a large decrease in the annual RH in Northern Ireland between 1965 and 2008, although (in contrast to our observations for Spain) they reported a greater decrease in winter and autumn. For the great Alpine region, Brunetti et al. (2009) reported a large decrease in RH over the last 30-40 years; this was mainly associated with a decrease in summer months, which is consistent with the trend observed in Spain. A similar reduction in RH has been reported in Poland (Wypych, 2010), Serbia (Gocic and Trajkovic, 2013), and the Czech Republic (Cahynova and Huth, 2009; Brazdil et al., 2009). Therefore, our results showing an abrupt decrease in $\mathrm{RH}$ for Spain are consistent with observations made in other regions of Europe over the last decade.

The pattern observed for $q$ was quite different (Fig. 5). Although various studies have shown a large increase in $q$ coinciding with global warming (e.g. Trenberth et al., 2005; Dai, 2006), which is expected because of the exponential $\mathrm{C}-\mathrm{C}$ relationship between temperature and atmospheric water vapor (Allan, 2012), for Spain we did not find major changes in $q$ between 1961 and 2011 at an annual scale. However, for spring and summer we observed an increase and a decrease, respectively, in the value of $q$, but the trends were not statistically significant. Willet et al. (2007) showed a significant global-scale increase in surface $q$ between 1975 and 2002, which was attributed to human-induced rising temperatures while $\mathrm{RH}$ remained approximately constant. We observed an increase in $q$ in Spain between 1973 and $2003\left(0.11 \mathrm{~g} \mathrm{~kg}^{-1}\right.$ decade $\left.^{-1}\right)$, but no significant increase was observed with respect to the entire 1961-2011 period. Consistent with Simmons et al. (2010), the evolution of $q$ over the last decade indicates a decrease in this parameter has occurred, mainly in the summer and annual series.

The spatial distribution of trends in $\mathrm{RH}$ and $q$ is shown in Figure 6. For RH, most stations showed negative and significant trends on both annual and seasonal bases. Annually, all series showed a negative trend, and only for four series was the trend not statistically significant (Table 1). Negative trends also dominated in winter, but the majority of stations near the Mediterranean Sea did not 
show significant trends, and four stations showed positive coefficients. In spring and summer there were no spatial differences, with all stations showing negative or negative and significant trends. Negative trends also dominated in autumn, but this pattern was mainly evident in the eastern part of Spain, whereas the stations located in the central and western parts of Spain tended to show nonsignificant trends. Trends in $q$ showed a more complex pattern. Positive trends were more common on an annual basis, with 35 stations showing positive coefficients and only 15 showing negative trends. Nevertheless, few stations (12) recorded positive and significant trends. With respect to spatial trends, the stations located in the north, close to the Atlantic Ocean and the Mediterranean coastline, tended to show more positive and significant trends than those located in inland areas. On a seasonal basis there were marked differences. In winter and autumn, nonsignificant changes dominated across Spain, but in spring only four stations showed negative trends, whereas the remaining 46 stations showed positive trends (22 of which were statistically significant). Spatial differences were very clear in spring, with positive and significant trends dominating in the northern and eastern parts of Spain, whereas in the central and southern regions the stations tended to show nonsignificant or even negative trends. For summer the spatial patterns were much more complex, although the stations in the north of Spain, located near the Atlantic Ocean, showed dominant positive and significant trends.

Figure 7 shows the spatial distribution of the changes in magnitude of $\mathrm{RH}$ and $q$ between 1961 and 2011. The changes in RH showed great spatial homogeneity, although greater changes occurred in summer in southern Spain than in northern areas. In general, the changes during summer oscillated between decreases of $1 \%$ decade $^{-1}$ to $2.5 \%$ decade $^{-1}$, and there was no marked difference between coastal and inland stations. There was a marked decrease in $q$ in the inland areas of southern Spain in summer. This could explain the contrasts observed at an annual scale between the stations located in central and southern Spain, where $q$ decreased at a rate of $0.10-0.15 \mathrm{~g} \mathrm{~kg}^{-1} \mathrm{decade}^{-1}$, and the northern stations, which showed a rate of increase in $q$ of $0.05-0.10 \mathrm{~g} \mathrm{~kg}^{-1} \mathrm{decade}^{-1}$. 


\subsection{Possible physical mechanisms}

The factors causing declines in $\mathrm{RH}$ across Europe have been hypothetically related to changes in wind direction in Ireland (Butler and García-Suárez, 2012) and atmospheric circulation processes in the Czech Republic (Cahynova and Huth, 2009). On the contrary, In the Alpine region, Brunnetti et al. (2009) pointed out a reduction of RH given vapour pressure increase (approximately $0.8 \mathrm{hPa}$ ), but not enough to balance the temperature increase of more than $1^{\circ} \mathrm{C}$. Saturation deficit by evaporation constraints is also pointed out by Wypych (2010) in Poland to explain general RH reduction since the observed increase in temperature is not matched by the vapour pressure variability. Here, we have analysed the connection with temperature variability and trends and the terrestrial and oceanic sources of moisture that supply atmospheric humidity to Spain.

\subsubsection{Surface temperature}

The importance of the warmer seasons in controlling the trends observed in both $\mathrm{RH}$ and $q$ at the annual scale was probably determined by the evolution of air temperature in Spain between 1961 and 2011, which in recent studies has been shown to have increased (e.g. Brunet et al., 2007; El Kenawy et al., 2012). For all 50 stations in the study we showed that in summer and spring, and at the annual scale, there was a positive and significant trend in the mean temperature (Table 1). A positive increase in temperature in winter and autumn was recorded at all stations, although the trend was not significant at every station. Based on a regional series for all of Spain, a large increase in both seasonal and annual temperature is evident (Fig. 8). Dai (2006) indicated that the general increase in $q$ observed in the decades of 1980 and 1990 was mainly attributable to a large increase in temperature over a short time period, which was consistent with the expected C-C relationship. Nevertheless, Simmons et al. (2010) noted a marked decrease in RH but not in q since 1999 (see also Willet et al., 2012) in agreement with increased temperature (See also Jones et al., 2010 and Hansen et al., 2010). A recent model ensemble study carried out by Ruosteenoja and Petri Räisänen (2013) has showed that RH will drop by $8 \%-12 \%$ in the southern European inland in summer by 
2070-99 (under the A1B scenario) as a response to global warming. We have observed this pattern for Spain between 1961 and 2011. Thus, the observed decrease in RH was consistent with a major increase in the surface air temperature. The mean annual temperature increased at a rate of $0.3^{\circ} \mathrm{C}$ decade $^{-1}$ between 1961 and 2011 , with the increase being greater in summer $\left(0.43^{\circ} \mathrm{C}\right.$ decade $\left.^{-1}\right)$ and spring $\left(0.37^{\circ} \mathrm{C}\right.$ decade $\left.^{-1}\right)$; this could explain why a greater decrease in RH was observed in these two seasons.

Because the temperature has increased by $1.5^{\circ} \mathrm{C}$ annually and $2.15^{\circ} \mathrm{C}$ in summer during the last five decades, based on the $\mathrm{C}-\mathrm{C}$ relationship $q$ should have increased at a rate of approximately $6.8 \% /{ }^{\circ} \mathrm{C}$ (Allan, 2012). Nevertheless, we found no change in $q$, and the commonly assumed small changes in RH (Soden and Held, 2006) have not been sustained in Spain. If $q$ remains constant under conditions of major temperature increase, this indicates that water supply to the atmosphere has not been sufficient to maintain constant $\mathrm{RH}$, independently of the temperature. The behavior of the sources of water supply to the atmosphere may be determining this pattern, suggesting that attention needs to be placed not just on how much moisture the atmosphere can hold (driven by the C-C relationship), but also on how moisture is supplied to the atmosphere (Jones et al., 2010).

\subsubsection{Sources of moisture}

The sources of atmospheric moisture are both oceanic and terrestrial (Gimeno et al., 2012). The former constitutes the main source of moisture in terrestrial areas, through atmospheric transport (advection) even from very distant areas (Gimeno et al., 2010). Nevertheless, terrestrial sources may also be important at regional (mesoscalar) and local scales, and seasonally may constitute a large proportion of the atmospheric supply through recycling processes (Dirmeyer and Brubaker, 2007; Millan et al., 2005). Gimeno et al. (2010) reported that there are two important source regions of atmospheric moisture in Spain: i) a tropical-subtropical North Atlantic corridor that extends from the Gulf of Mexico to the Iberian Peninsula; and ii) the Iberian Peninsula itself and the surrounding 
western Mediterranean basin. The former dominates during colder periods and the latter during warmer periods, because of the dominant atmospheric circulation patterns.

\section{a) Terrestrial sources}

Soil moisture and recycling processes driven by evapotranspiration are very active sources during summer (Eltahir, 1998; Juang et al., 2007). The atmosphere in Spain is stable in summer, but convective processes mainly driven by barocline mesoscale boundaries (e.g. sea breeze fronts; Azorin-Molina et al., 2009) supply moisture, along with the terrestrial water stored in the form of soil moisture. The level of soil moisture is highly dependent on antecedent precipitation. Although changes in precipitation in Spain in recent decades have been less than the changes in temperature, at the annual scale the trend in precipitation has been negative $\left(-18.7 \mathrm{~mm}\right.$ decade $\left.^{-1}\right)$ and statistically significant $(p<0.05$; Fig. 9). Thus, mean annual precipitation decreased by $16 \%$ over the past five decades, from $600.7 \mathrm{~mm}$ in 1961 to $507.1 \mathrm{~mm}$ in 2011. This decrease has paralleled a decrease in cloud cover over Spain since the 1960s (Sanchez-Lorenzo et al., 2009, 2012). As a consequence of marked interannual variability in precipitation the decrease in precipitation in winter and summer over the last 50 years has not been statistically significant, but nonetheless has been substantial: a $25 \%$ decrease in winter (from 194.3 to $145.8 \mathrm{~mm}$ ) and a $24 \%$ decrease in summer (from 77.5 to $58.8 \mathrm{~mm})$.

There is a positive (negative) relationship between the temporal variability of $\mathrm{RH}$ and precipitation (temperature) in Spain. Figure 10 shows the relationship of annual precipitation and annual temperature to the annual RH obtained from the regional series for all of Spain. The analysis included direct correlation of the series, but also a correlation among the de-trended series (removing the linear trend for the period 1961-2011), to determine whether temporal anomalies in precipitation and temperature could be affecting $\mathrm{RH}$ anomalies independently of the observed trends in the three variables. For the original series, temperature showed a greater correlation than precipitation, but for the de-trended series the correlation decreased markedly, which suggests that 
the temporal anomalies in RH were highly determined by both variables. However, the strong negative trend in $\mathrm{RH}$ identified at the annual scale was mostly driven by the evolution of temperature. This pattern was also observed for the stations individually. Figure 11 shows box plots representing the statistical distribution of correlations among precipitation, temperature and $\mathrm{RH}$ for the stations involved in the study. The patterns are similar to the pattern for the regional series. In spring, summer, autumn and annually, the correlations between temperature and $\mathrm{RH}$ decreased when the de-trended series were used in the analysis, suggesting that the RH anomalies were mostly driven by precipitation variability than by temperature, but the trends were driven by temperature increase. Winter was the exception, as the correlations between the de-trended series of temperature and RH were positive. In general, winter is a humid period in Spain; this could explain the positive correlation between $\mathrm{RH}$ and temperature, as there are no constraints on the supply of moisture to the atmosphere from terrestrial and oceanic sources. This pattern (together with the small temperature increase in winter between 1961 and 2011, and the low temperatures that favor small variations in $\mathrm{RH}$ ) indicates that the evolution of $\mathrm{RH}$ during winter was more constant than in other seasons and was mainly driven by temperature (i.e. by the capacity of the atmosphere to hold water). The box plots showing correlations between $q$ and the original and de-trended series show clearly that there was no substantial difference in correlation between the original and the de-trended series (Fig. 12). This indicates that despite the interannual anomalies of $q$ being heavily influenced by temperature variability, the observed trend in $q$ was not driven by the temporal evolution of temperature; rather, constraints on water supply to the atmosphere from various sources probably had a strong influence on the evolution of $q$.

Although in many areas of Spain winter precipitation does not provide the greatest seasonal contribution (de Luis et al., 2010), winter precipitation is crucial for soil moisture recharge because it is a period of very low evapotranspiration, and a high percentage of the precipitation is stored in the soil; this is of great importance for the levels of soil moisture and vegetation activity in the following spring and summer (Austin et al., 1998). This is one of the likely reasons for the positive 
trend in $q$ during spring. The same general behavior occurred in autumn, which is the only season in which in recent decades there has been increased precipitation in at least in some areas of Spain, particularly the northwest (González-Hidalgo et al., 2011). Moreover, precipitation in the form of storms that develop over the mountain ridges is very important during the summer (Álvarez et al., 2011). Thus, the decrease in precipitation is likely to be reducing the moisture available for transfer to the atmosphere. The precipitation decrease observed in warm season probably had a marked impact on the supply of water to the atmosphere when the greatest increase in temperature and the greatest decrease in $\mathrm{RH}$ were recorded. The evolution of the SPEI shows that severe drought events dominated mainland Spain in the 1990s and the 2000s (Fig. 13), consistent with the pattern already observed in most of the Mediterranean basin (Hoerling et al., 2012). Stronger climate drought events are directly propagated to the hydrological cycle and reduce the availability of soil moisture, as recently demonstrated by modeling experiments (Van Loon et al., 2012).

An indirect indicator of a decrease in the supply of moisture from terrestrial areas to the atmosphere may be the decrease in evapotranspiration that has occurred over land areas since 1998 (Jung et al., 2011). This was probably related to reduced soil moisture availability, and could be contributing to the recent decrease in RH, reported at the global scale by Simmons et al. (2010). We have no information on real evapotranspiration (ET) in Spain, but the evolution of both precipitation and the SPEI suggests that ET is probably decreasing because of reduced availability of soil moisture, as opposed to increased PET (Espadafor et al., 2011). In addition, Spain is affected by complex land cover change processes in recent decades (Stellemes et al., 2013; Hill et al., 2008; Lasanta and Vicente-Serrano, 2012), being the most relevant the creation of new irrigated lands (GonzalezFerrando, 2003; Grindlay et al., 2011) and the increased forest coverage in mountain areas as a consequence of land margination and rural abandonment (Lasanta et al., 2005; Lasanta 2007). Therefore, it would be expected that new irrigated lands and forests may contribute to supply more humidity to the atmosphere given higher ET rates than previous coverages (dry land agricultural areas and pastures). Irrigated lands have increased by $48 \%$ between 1961 and 2011. Nevertheless, 
the irrigated surface is low in comparison to the total surface in Spain (7\%); it is only relevant for ET during summer months; and it is also affected by water restrictions in drought years (Quiroga et al., 2011). In addition, increased forest lands combined with less precipitation may have an effect on a faster decline of soil water storage and contribute to evapotranspiration and vegetation water stress. Thus, an indirect indicator of reduced moisture availability (and consequently a reduced supply of moisture to the atmosphere) may be increased water stress in the vegetation in natural areas. This vegetation has undergone a marked decline in growth and activity, particularly in areas affected by limiting environmental conditions (including aridity, low water field capacity, southern slopes) (Sánchez-Salguero et al., 2012; Carnicer et al., 2012; Vicente-Serrano et al., 2010).

Other indirect evidence for a decrease in the terrestrial water supply is the decrease in the number of summer precipitation events with examples in the east (Millan et al. 2005b) and northeast Spain (López-Moreno et al., 2010), which are driven by convective processes and require high levels of RH to be generated (Martin et al., 2006). Gallego et al. (2011) reported for Spain an increase in light precipitation events but a decrease affecting intense precipitation cases, which could explain the stationary q values at the surface. Thus, Millán et al. (2005) suggested that the summer climate in Spain may be changing from an open monsoon-type regime with frequent summer storms to one dominated by closed vertical recirculation, where feedback mechanisms favor a reduction in storms because of the lack of moisture supply. Rowell and Jones (2006) showed that this mechanism may be enhanced in the future and generate a positive feedback mechanism in summer, whereby reduced rainfall results in further drying of the soil, reducing convective activity. Therefore, although the atmosphere may be holding more moisture because of increased temperature, a reduction in terrestrial water supply in Spain could in part explain the observed trend in RH and stationary $q$ evolution.
b) Oceanic sources 
441 The atmospheric supply of water from the ocean could also be reduced by changes in the magnitude 442 of the warming processes between terrestrial and oceanic areas. Simmons et al. (2010) argued that 443 while the average temperature over the land has continued to rise in recent years, the temperature of 444 the sea surface has not. Therefore, along with terrestrial processes, the decline in RH over the land 445 could be favored by the absence of an increase in supply of water from the ocean. Thus, Figure 14 446 shows the evolution of the SST (based on the three datasets indicated in section 2.2) in the two main 447 areas (Gimeno et al., 2010b) that supply atmospheric humidity to the Iberian Peninsula. The results 448 are very similar, irrespective of the dataset used. In both the tropical-subtropical North Atlantic 449 corridor (Zone 1 in Fig. 15) and the surrounding Mediterranean (Zone 2 in Fig. 15) there was an 450 increase in SST at both the annual and seasonal scales between 1961 and 2011. Nevertheless, the magnitude of the SST increase was much lower than that observed for land temperatures. Moreover, at the annual and seasonal scales the SST did not increase in either area after 1995. Figure 15 also shows that between 1981 and 2011 the spatial distribution of changes in SST in the region were minor in magnitude. Only in summer and in areas close to the Iberian Peninsula were the changes statistically significant. Therefore, the higher maximum summer temperature of the land surface relative to the ocean might in part explain the observed decline in maximum RH values at high temperatures. This is because the presence of a saturated parcel of static air over the ocean could 458 reduce the flow of humid air from oceanic areas to the landmass of Spain, which could contribute to 459 sub-saturation of the air over the warmer land surface. This highlights the limitations of using present day scaling relationships based solely on land surface temperatures and the C-C relationship, without regard to moisture availability and its generation in the source regions.

\section{Environmental and social implications}

464 The observed decrease in RH over Spain may have large implications for the availability of water resources, crop production and ecosystems. RH is important in explaining anomalies in PET, which is essentially dependent on four meteorological variables: air temperature, solar radiation, $\mathrm{RH}$ and 
wind speed (Allen et al., 1998; Liu and McVicar, 2012). Thus, some studies have showed that PET anomalies are mostly driven by solar radiation and RH, and less so by temperature (Hidalgo et al., 2005; Wang et al., 2010). In a sensitivity study in the Yangtze River catchment in China, Xu et al. (2006) showed that changes in RH contributed significantly to explaining relative changes in PET, and Espadafor et al. (2011) showed similar results in southern Spain. The increasing water demand by the atmosphere over Spain is causing a decrease in forest growth rates both in semiarid sites (Vicente-Serrano et al., 2010c; Carnicer et al., 2012) and humid forests (Galiano et al., 2010; Camarero et al., 2011; Sánchez-Salguero et al., 2012; Linares and Camarero, 2012), and some aridification of climate, which is triggering local desertification processes in vulnerable semiarid Mediterranean environments (Vicente-Serrano et al., 2012b). RH is also a determinant of ablation processes in glacier environments (Strasser et al., 2004), with implications for the survival of the last vestiges of glacial masses located in the Pyrenees (Chueca et al., 2005).

Reduced levels of RH may also exacerbate the severity of drought events. The evolution of the SPEI in Spain clearly shows recent intensification in the severity of droughts, and the observed trend in RH is probably reinforcing the negative effects of droughts on vegetation. This is because the surface humidity affects the wetness of plant leaf surfaces (Klemm et al., 2002) and the duration of leaf wetness, which is a key parameter in agricultural meteorology; it is related to disease in many important crops because it controls pathogen infection and development rates (Sentelhas et al., 2008).

Surface humidity is also important in explaining variations in pollutant concentrations in Spain. Castell et al. (2008) showed that in eastern Spain there is an inverse relationship between RH and the concentration of tropospheric ozone. Water vapor in the atmosphere may enhance the removal of highly reactive radicals, which are precursors of ozone formation. Thus, a generalized decrease in RH in Spain could be associated with more frequent pollution episodes affecting human health. Several studies in Spain have shown that the level of surface humidity has an influence on human mortality and the incidence of a number of diseases. Alberdi et al. (1998) showed that high RH 
during summer was negatively correlated to mortality in central Spain between 1986 and 1992. Paradoxically, a decrease in RH in Spain may also have positive consequences for health. For example, Oliveira et al. (2009) reported that in the western Iberian Peninsula there was a positive correlation between potentially allergenic spring-autumn spores and the RH. In addition, decreased RH has been associated with decreased pain and rigidity in arthritis sufferers (Aikman, 1997), lower respiratory virus activity (Hervás et al., 2012), and decreased mortality among elderly people resulting from cardiovascular, respiratory and digestive causes in winter in central Spain (Fernández-Raga, 2010). Beyond health effects, the marked negative agricultural, hydrological and environmental impacts of decreased RH outweigh the possible advantages. Forest fire is one of the main natural hazards affecting Spain (Martínez et al., 2009), and RH is a significant parameter affecting the development and spatial propagation of forest fires, which are favored by low rates of RH (e.g. Flannigan and Harrington, 1988). Thus, the most severe forest fires in Spain in recent years have coincided with conditions of low soil moisture, drought and low levels of RH (Pausas, 2004), and these factors are clearly contributing to the increased area affected (Pausas and Fernández-Muñoz, 2012).

\section{Summary and conclusion}

This study has analysed the evolution of RH and q in Spain by means of complete available records from the Spanish National Meteorological Agency. A careful quality control and homogeneity protocol has allowed having 50 series across Spain that allowed to analyse recent surface humidity variability and trends. We have shown that a large decrease in RH occurred in Spain between 1961 and 2011. This has been associated with a marked increase in temperature during the same period but, in contrast, no change in specific humidity. Our results suggest that the evolution of surface humidity in the last five decades was not uniquely driven by the Clausius-Clapeyron relationship, which determines how much moisture the atmosphere can hold. We found constraints on the supply of moisture to the atmosphere from the main terrestrial and oceanic sources, specifically a reduction 
in precipitation and soil moisture in the case of terrestrial sources, and stable sea surface temperatures that could be reducing the flow of atmospheric moisture to mainland Spain.

\section{Acknowledgements}

The authors are grateful to J.C. González-Hidalgo for his helpful comments on the first draft of this article. We would like to thank the Spanish Meteorological State Agency (AEMET) for providing

Technology and FEDER, "Efecto de los escenarios de cambio climático sobre la hidrología superficial y la gestión de embalses del Pirineo Aragonés" financed by "Obra Social La Caixa" and the Aragón Government and Influencia del cambio climático en el turismo de nieve, CTTP01/10,

Financed by the Comisión de Trabajo de los Pirineos.

\section{References}

Aikman, H., (1997): The association between arthritis and the weather. Int J Biometeorol 40:192199

Alberdi, J.C., Díaz, J., Montero, J.C, Mirón, I., (1998): Daily mortality in Madrid community 19861992: relationship with meteorological variables. European Journal of Epidemiology, 14: 571-578.

Alexandersson, H., (1986): A homogeneity test applied to precipitation data. Journal of Climatology, 6: 661-675.

Allan, R.P. (2012): The Role of Water Vapour in Earth's Energy Flows. Surveys in Geophysics 33: 557-564.

Allen, R.G., Pereira, L.S., Raes, D. and Smith, M., (1998): Crop evapotranspiration: guidelines for computing crop requeriments. Irrigation and drainage paper 56. FAO. Rome.

Álvarez, E., Espejo, F., Cortés, F.J., Lafragüeta, C. and Serrano, R. (2011): Caracterización sinóptica de los procesos convectivos en el interior del nordeste peninsular. Nota Técnica 3 de AEMET. Agencia Estatal de Meteorología. Available on-line at:

http://www.aemet.es/documentos/es/conocermas/publicaciones/Sinoptica/NT_AEMET_3.pdf

Austin, R.B., Cantero-Martínez, C., Arrúe, J.L., Playán, E. and Cano-Marcellán, P., (1998): Yieldrainfall relationships in cereal cropping systems in the Ebro river valley of Spain. European Journal of Agronomy, 8: 239-248.

Azorin-Molina, C., Connell, B.H., Baena-Calatrava, R. (2009): Sea-breeze convergence zones from AVHRR over the Iberian Mediterranean area and the Isle of Mallorca, Spain. Journal of Applied Meteorology and Climatology 48: 2069-2085.

Brázdil, R. , Chromá, K., Dobrovolný, P., Tolasz, R. (2008): Climate fluctuations in the Czech Republic during the period 1961-2005. International Journal of Climatology. 22: 2982-2992.

Brown, P. and DeGaetano, A.T., (2012): Trends in U.S. surface humidity, 1930 - 2010. Journal of Applied Meteorology and Climatology. doi: http://dx.doi.org/10.1175/JAMC-D-12-035.1 
Brunet, M., Jones, P.D., Sigro, J., Saladie, O., Aguilar, E., Moberg, A., Della- Marta, P.M., Lister, D., Walther, A., López, D., 2007. Temporal and spatial temperature variability and change over Spain during 1850-2005. J. Geophys. Res. 112, D12117. doi:10.1029/2006JD008249.

Brunetti, M. et al., (2009): Climate variability and change in the Greater Alpine Region over the last two centuries based on multi-variable analysis. International Journal of Climatology, 29: 2197-2225.

Butler, C. J. and García-Suárez, A. M. (2012), Relative humidity at Armagh Observatory, 18382008. Int. J. Climatol., 32: 657-668.

Cahynová, M., Huth, R., (2009): Changes of atmospheric circulation in central Europe and their influence on climatic trends in the Czech Republic. Theor Appl Climatol. 96: 57-68.

Camarero, J.J., Bigler, C., Linares, J.C., Gil-Pelegrín, E. (2011): Synergistic effects of past historical logging and drought on the decline of Pyrenean silver fir forests. Forest Ecology and Management 262: 759-769

Carnicer, J., Coll, M., Ninyerola, M., Pons, X., Sánchez, G., Peñuelas, J. (2011): Widespread crown condition decline, food web disruption, and amplified tree mortality with increased climate change-type drought. Proceedings of the National Academy of Sciences of the United States of America 108: 1474-1478.

Castell, N., Enrique Mantilla, Millan M. Millan, (2008): Analysis of tropospheric ozone concentration on a Western Mediterranean site: Castellon (Spain). Environ Monit Assess, 136: 3-11

Chueca Cía, J., Julián Andrés, A., Saz Sánchez, M.A., Creus Novau, J., López Moreno, J.I. (2005): Responses to climatic changes since the Little Ice Age on Maladeta Glacier (Central Pyrenees). Geomorphology 68: 167-182

Dai, A. (2006): Recent climatology, variability, and trends in global surface humidity. Journal of Climate 19: 3589-3606.

de Luis, M., Brunetti, M., Gonzalez-Hidalgo, J.C., Longares, L.A., Martin-Vide, J. (2010): Changes in seasonal precipitation in the Iberian Peninsula during 1946-2005. Global and Planetary Change 74: 27-33.

Dirmeyer, P.A., Brubaker, K.L. (2007): Characterization of the global hydrologic cycle from a back-trajectory analysis of atmospheric water vapor. Journal of Hydrometeorology 8: 20-37.

Eltahir, E.A.B. (1998): A soil moisture-rainfall feedback mechanism 1. Theory and observations. Water Resources Research 34: 765-776.

El Kenawy, A., López-Moreno, J.I., Vicente-Serrano, S.M., (2012): Trend and variability of temperature in northeastern Spain (1920-2006): linkage to atmospheric circulation. Atmospheric Research. Atmospheric Research 106: 159-180.

Espadafor, M., Lorite, I.J., Gavilán, P., Berengena, J. (2011): An analysis of the tendency of reference evapotranspiration estimates and other climate variables during the last 45 years in Southern Spain. Agricultural Water Management, 98: 1045-1061.

Fernández-Raga, M., Clemente Tomás, Roberto Fraile (2010): Human mortality seasonality in Castile-León, Spain, between 1980 and 1998: the influence of temperature, pressure and humidity. Int J Biometeorol 54: 379-392

Flannigan, M.D. and Harrington, J.B., (1988): A study of the relation of meteorological variables to monthly provincial area burned by wilfire in Canada (1953-1980). Journal of Applied Meteorology, 27: 441-452.

Gaffen, D.J., Ross, R.J. (1999): Climatology and trends of U.S. surface humidity and temperature. Journal of Climate 12: 811-828.

Galiano, L., Martínez-Vilalta, J., Lloret, F. (2010): Drought-Induced Multifactor Decline of Scots Pine in the Pyrenees and Potential Vegetation Change by the Expansion of Co-occurring Oak Species. Ecosystems 13: 978-991.

Gallego, M.C., Trigo, R.M., Vaquero, J.M., Brunet, M., García, J.A., Sigró, J., Valente, M.A. (2011): Trends in frequency indices of daily precipitation over the Iberian Peninsula during the last century. Journal of Geophysical Research D: Atmospheres 116 (2), art. no. D02109 
Gimeno, L., A. Drumond, R. Nieto, R.M. Trigo, A. Stohl (2010) On the origin of continental precipitation, Geophysical Research Letters, 37, doi: 10.1029/2010GL043712

Gimeno, L., Nieto, R., Trigo, R.M., Vicente-Serrano, S.M. and López-Moreno, J.I., (2010b) Where does the Iberian Peninsula moisture come from? An answer based on a Lagrangian approach. Journal of Hydrometeorology 11, 421-436.

Gimeno, L., et al., (2012): Oceanic and terrestrial sources of continental precipitation. Reviews of Geophysics 50 (4), art. no. RG4003.

Giorgi, F., Lionello, P. (2008): Climate change projections for the Mediterranean region. Global and Planetary Change 63: 90-104.

Gocic, M. , Trajkovic, S. (2013): Analysis of changes in meteorological variables using MannKendall and Sen's slope estimator statistical tests in Serbia. Global and Planetary Change 100: 172-182.

González-Ferrando, S. (2003): Situación actual y perspectivas del regadío en España. Revista Española de Estudios Agrosociales y Pesqueros, 200-II: 1117-1137González-Hidalgo, J.C., Brunetti, M., de Luis, M. (2011): A new tool for monthly precipitation analysis in Spain: MOPREDAS database (monthly precipitation trends December 1945-November 2005). International Journal of Climatology 31: 715-731.

Grindlay, A.L., Lizárraga, C., Rodríguez, M.I., Molero, E. (2011): Irrigation and territory in the southeast of Spain: Evolution and future perspectives within new hydrological planning. WIT Transactions on Ecology and the Environment 150: 623-638.

Hamed, A., Korhonen, H., Sihto, S.-L., Joutsensaari, J., Jrvinen, H., Petäjä, T., Arnold, F., Nieminen, T., Kulmala, M., Smith, J.N., Lehtinen, K.E.J., Laaksonen, A. (2011): The role of relative humidity in continental new particle formation. Journal of Geophysical Research D: Atmospheres 216, Article number D03202.

Hansen, J., Ruedy, R., Sato, M., Lo, K., (2010): Global surface temperature change. Reviews of Geophysics. 48, RG4004, doi: 10.1029/2010RG000345.

Hargreaves GL, Samani ZA. 1985. Reference crop evapotranspiration from temperature. Applied Engineering in Agriculture 1: 96-99.

Hervás, D., Reina, J., Hervás, J.A. (2012): Meteorologic conditions and respiratory syncytial virus activity. Pediatric Infectious Disease Journal. 31: 176-181

Hidalgo, H.G., Cayan, D.R., Dettinger, M.D. (2005): Sources of variability of evapotranspiration in California. Journal of Hydrometeorology 6: 3-19.

Hill, J., Stellmes, M., Udelhoven, Th., Röder, A., Sommer, S. (2008): Mediterranean desertification and land degradation. Mapping related land use change syndromes based on satellite observations Global and Planetary Change 64: 146-157.

Hoerling, M., Eischeid, J., Perlwitz, J., Quan, X., Zhang, T., Pegion, P. (2012): On the increased frequency of mediterranean drought. Journal of Climate 25: 2146-2161.

Isaac, V., Van Wijngaarden, W.A. (2012): Surface water vapor pressure and temperature trends in North America during 1948-2010. Journal of Climate 25: 3599-3609.

Jones, P.D. and Hulme, M., (1996): Calculating regional climatic time series for temperature and precipitation: methods and illustrations. International Journal of Climatology. 16: 361-377.

Jones, R.H., Seth Westra and Ashish Sharma (2010): Observed relationships between extreme sub-daily precipitation, surface temperature, and relative humidity. Geophysical Research letters 37, L22805, doi:10.1029/2010GL045081.

Jones, P.D., Lister, D.H., Osborn, T.J., Harpham, C., Salmon, M., Morice, C.P. (2012): Hemispheric and large-scale land-surface air temperature variations: An extensive revision and an update to 2010. Journal of Geophysical Research D: Atmospheres 117 (5), art. no. D05127.

Juang, J.-Y., Porporato, A., Stoy, P.C., Siqueira, M.S., Oishi, A.C., Detto, M., Kim, H.-S., Katul, G.G. 2007 Hydrologic and atmospheric controls on initiation of convective precipitation events. Water Resources Research 43 (3), art. no. W03421. 
Jung, M., et al., (2010): Recent decline in the global land evapotranspiration trend due to limited moisture supply. Nature 467: 951-954.

Karl, T.R., and Williams, C.N., (1987): An approach to adjusting climatological time series for discontinuous inhomogeneities. Journal of Climate and Applied Meteorology. 26: 17441763.

Kendall MG, Gibbons JD. (1990): Rank Correlation Methods (5th edition). London: Arnold.

Klemm, O., Milford, C., Sutton, M.A., Spindler, G., Van Putten, E. (2002): A climatology of leaf surface wetness. Theoretical and Applied Climatology 71: 107-117.

Lanzante, J.R., (1996): Resistant, robust and non-parametric techniques for the analysis of climate data: theory and examples, including applications to historical radiosonde station data. International Journal of Climatology. 16: 1197-1226.

Lasanta, T., Vicente Serrano, S.M. and Cuadrat, J.M., (2005), Spatial-temporal variability of the plant landscape in the mediterranean highlands due to the abandonment of traditional land uses: a study of the Spanish Central Pyrenees. Applied Geography 25: 47-65.

Lasanta, T. (2007): El paisaje de la montaña mediterránea: Cambios por el abandono de tierras agrícolas. Cuadernos de la Sostenibilidad y Patrimonio Natural 11: 58- 69.

Lasanta, T. and Vicente-Serrano, S.M., (2012) Complex land cover change processes in semiarid Mediterranean regions: an approach using Landsat images in northeast Spain. Remote Sensing of Environment. 124: 1-14.

Linares, J.C., Camarero, J.J. (2012): Growth patterns and sensitivity to climate predict silver fir decline in the Spanish Pyrenees. European Journal of Forest Research 131: 1001-1012

Liu, Q., McVicar, T.R. (2012): Assessing climate change induced modification of Penman potential evaporation and runoff sensitivity in a large water-limited basin. Journal of Hydrology 464465: 352-362.

López-Moreno, J.I., Vicente-Serrano, S.M., Beguería, S., El Kenawy, A.M., Angulo M. (2010): Trends in daily precipitation on the north-eastern Iberian Peninsula, 1955-2006. International Journal of Climatology 30: 1026-1041.

Martín, M.L., Santos-Muñoz, D., Morata, A., Luna, M.Y., Valero, F. 2006 An objectively selected case study of a heavy rain event in the Mediterranean Basin: A diagnosis using numerical simulation. Atmospheric Research 81: 187-205.

Martínez, J., Vega-Garcia, C., Chuvieco, E. (2009): Human-caused wildfire risk rating for prevention planning in Spain. Journal of Environmental Management 90: 1241-1252.

Millán, M.M. et al., (2005): Climatic feedbacks and desertification: The Mediterranean model. Journal of Climate 18: 684-701.

Millán, M.M., Estrela, M.J., Miró, J. (2005b): Rainfall components: Variability and spatial distribution in a Mediterranean area (Valencia region). Journal of Climate 18: 2682-2705.

Meehl, G., et al. (2007), Global climate projections, in Climate Change 2007: The Physical Science Basis. Contribution of Working Group I to the Fourth Assessment Report of the Intergovernmental Panel on Climate Change, edited by S. Solomon et al., pp. 747-845, Cambridge Univ. Press, Cambridge, U. K.

Norrant, C., Douguédroit, A. (2006): Monthly and daily precipitation trends in the Mediterranean (1950-2000). Theoretical and Applied Climatology 83: 89-106.

Oliveira, M., H. Ribeiro, J. L. Delgado, I. Abreu (2009): The effects of meteorological factors on airborne fungal spore concentration in two areas differing in urbanisation level. Int $\mathbf{J}$ Biometeorol 53:61-73

Oort. A.H., (1983). Global atmospheric circulation statistics. 1958-1973. NOAA Prof paper 14. 180 pp and 47 microfiches.

Pausas, J.G. 2004 Changes in fire and climate in the eastern Iberian Peninsula (Mediterranean Basin). Climatic Change 63: 337-350.

Pausas J.G. and Fernández-Muñoz S. (2012). Fire regime changes in the Western Mediterranean Basin: from fuel-limited to drought-driven fire regime. Climatic Change 110: 215-226 
Peterson, T.C. and Easterling, D.R., (1994): Creation of homogeneous composite climatological reference series. International Journal of Climatology. 14: 671-679.

Peterson, T.C., Easterling, D.R., Karl, T.R., et al., (1998): Homogeneity adjustments of in situ atmospheric climate data: a review. International Journal of Climatology. 18: 1493-1517.

Quiroga, S., Garrote, L., Iglesias, A., Fernández-Haddad, Z., Schlickenrieder, J., De Lama, B., Mosso, C., Sánchez-Arcilla, A. (2011): The economic value of drought information for water management under climate change: A case study in the Ebro basin. Natural Hazards and Earth System Science 11: 643-657.

Rayner, N. A.; Parker, D. E.; Horton, E. B.; Folland, C. K.; Alexander, L. V.; Rowell, D. P.; Kent, E. C.; Kaplan, A. (2003) Global analyses of sea surface temperature, sea ice, and night marine air temperature since the late nineteenth century J. Geophys. Res.Vol. 108, No. D14, 4407 10.1029/2002JD002670.

Reynolds, R. W., N. A. Rayner, T. M. Smith, D. C. Stokes and W. Wang, 2002: An improved in situ and satellite SST analysis for climate. J. Climate, 15, 1609-1625.

Ruosteenoja, K. and Räisänen, P., (2013): Seasonal Changes in Solar Radiation and Relative Humidity in Europe in Response to Global Warming. J. Climate, 26, 2467-2481.

Rowell, D.P., Richard G. Jones (2006): Causes and uncertainty of future summer drying over Europe Climate Dynamics 27: 281-299.

Stellmes, M., Röder, A., Udelhoven, T., Hill, J. (2013): Mapping syndromes of land change in Spain with remote sensing time series, demographic and climatic data. Land Use Policy 30: 685-702

Trenberth KE (1999) Atmospheric moisture recycling: role of advection and local evaporation. J Climate 12:1368-1381.

Trenberth, K.E., John Fasullo, Lesley Smith (2005): Trends and variability in column-integrated atmospheric water vapor. Climate Dynamics 24: 741-758.

Trenberth, K.E., P.D. Jones, P. Ambenje, R. Bojariu, D. Easterling, A. Klein Tank, D. Parker, F. Rahimzadeh, J.A. Renwick, M. Rusticucci, B. Soden and P. Zhai, 2007: Observations: Surface and Atmospheric Climate Change. In: Climate Change 2007: The Physical Science Basis. Contribution of Working Group I to the Fourth Assessment Report of the Intergovernmental Panel on Climate Change [Solomon, S., D. Qin, M. Manning, Z. Chen, M. Marquis, K.B. Averyt, M. Tignor and H.L. Miller (eds.)]. Cambridge University Press, Cambridge, United Kingdom and New York, NY, USA.

Sánchez-Salguero, R., Navarro-Cerrillo, R.M., Camarero, J.J., Fernández-Cancio, Á. (2012): Selective drought-induced decline of pine species in southeastern Spain. Climatic Change 113: 767-785.

Sanchez-Lorenzo, A., Calbó, J., Brunetti, M., Deser, C. (2009): Dimming/brightening over the Iberian Peninsula: Trends in sunshine duration and cloud cover and their relations with atmospheric circulation. Journal of Geophysical Research D: Atmospheres 114 (8), art. no. D00D09

Sanchez-Lorenzo, A., J. Calbó and M. Wild (2012): Increasing cloud cover in the 20th century: review and new findings in Spain. Climate of the Past 8, 1199-1212.

Santer, B.D., Mears, C., Wentz, F.J., Taylor, K.E., Gleckler, P.J., Wigley, T.M.L., Barnett, T.P., et al. (2007): Identification of human-induced changes in atmospheric moisture content. Proceedings of the National Academy of Sciences of the United States of America 104: 15248-15253.

Seidel, T.M., Grant, A.N., Pszenny, A.A.P., Allman, D.J. (2007): Dewpoint and humidity measurements and trends at the summit of Mount Washington, New Hampshire, 1935-2004. Journal of Climate 20: 5629-5641.

Sentelhas, P.C., Anna Dalla Marta, Simone Orlandini, Eduardo A. Santos, Terry J. Gillespie, Mark L. Gleason (2008): Suitability of relative humidity as an estimator of leaf wetness duration. Agricultural and forest meteorology 148: 392-400. 
Simmons, A.J., Willett, K.M., Jones, P.D., Thorne, P.W., Dee, D.P. (2010): Low-frequency variations in surface atmospheric humidity, temperature, and precipitation: Inferences from reanalyses and monthly gridded observational data sets. Journal of Geophysical Research D: Atmospheres 115, art. no. D01110.

Smith, T.M., R.W. Reynolds, Thomas C. Peterson, and Jay Lawrimore, 2008: Improvements to NOAA's Historical Merged Land-Ocean Surface Temperature Analysis (1880-2006). Journal of Climate, 21, 2283-2296.

Soden, B. J., and I. M. Held (2006), An assessment of climate feedbacks in coupled ocean-atmosphere models, J. Clim., 19, 3354-3360,

Solomon, S., D. Qin, M. Manning, Z. Chen, M. Marquis, K.B. Averyt, M. Tignor and H.L. Miller (eds.). (2007): Climate Change 2007: The Physical Science Basis. Cambridge University Press, Cambridge, United Kingdom and New York, NY, USA,

Stepanek, P., (2003): Homogeneización de las series de temperatura del aire en la República Checa durante el período instrumental. Geographicalia. 43: 5-24.

Stepanek, P., (2012): Anclim Software. http://www.climahom.eu/software-solution/anclim.

Strasser, U., Corripio, J., Pellicciotti, F., Burlando, P., Brock, B., Funk, M. (2004): Spatial and temporal variability of meteorological variables at Haut Glacier d'Arolla (Switzerland) during the ablation season 2001: Measurements and simulations. Journal of Geophysical Research D: Atmospheres 109: D03103 1-18

Van Loon, A.F., M. H. J. Van Huijgevoort, and H. A. J. Van Lanen (2012): Evaluation of drought propagation in an ensemble mean of large-scale hydrological models. Hydrol. Earth Syst. Sci., 16, 4057-4078.

van Wijngaarden, W.A., Vincent, L.A. (2005): Examination of discontinuities in hourly surface relative humidity in Canada during 1953-2003. Journal of Geophysical Research D: Atmospheres 110. art. no. D22102.

Vicente-Serrano, S.M., Beguería, S., Juan I. López-Moreno, Miguel A. García-Vera and P. Stepanek. (2010): A complete daily precipitation database for North-East Spain: reconstruction, quality control and homogeneity. International Journal of Climatology. 30, 1146-1163.

Vicente-Serrano S.M., Santiago Beguería, Juan I. López-Moreno, (2010b) A Multi-scalar drought index sensitive to global warming: The Standardized Precipitation Evapotranspiration Index - SPEI. Journal of Climate 23: 1696-1718.

Vicente-Serrano, S.M., Lasanta, T., Gracia, C., (2010c): Aridification determines changes in leaf activity in Pinus halepensis forests under semiarid Mediterranean climate conditions. Agricultural and Forest Meteorology 150, 614-628.

Vicente-Serrano, S.M., Santiago Beguería, Jorge Lorenzo-Lacruz, Jesús Julio Camarero, Juan I. López-Moreno, Cesar Azorin-Molina, Jesús Revuelto, Enrique Morán-Tejeda and Arturo Sánchez-Lorenzo. (2012) Performance of drought índices for ecological, agricultural and hydrological applications. Earth Interactions 16, 1-27.

Vicente-Serrano, S.M., Aidel Zouber, Teodoro Lasanta, and Yolanda Pueyo. (2012); Dryness is accelerating degradation of vulnerable shrublands in semiarid Mediterranean environments. Ecological Monographs, 82, 407-428.

Wang, K., Dickinson, R.E., Wild, M., Liang, S. (2010): Evidence for decadal variation in global terrestrial evapotranspiration between 1982 and 2002: 1. Model development. Journal of Geophysical Research D: Atmospheres 115 (20), art. no. D20113.

Wang, K., Dickinson, R.E. (2012): A review of global terrestrial evapotranspiration: Observation, modeling, climatology, and climatic variability. Reviews of Geophysics 50 (2) , art. no. RG2005

Wexler, A. (ed.), (1965): Humidity and Moisture. Volumes 1 and 3, Reinhold, New York.

Willett, K.M., Gillett, N.P., Jones, P.D., Thorne, P.W. (2007): Attribution of observed surface humidity changes to human influence. Nature 449: 710-712. 
Willett, K.M., C. N. Williams Jr., R. J. H. Dunn, P. W. Thorne, S. Bell, M. de Podesta, P. D. Jones, and D. E. Parker (2012): HadISDH: an updated land surface specific humidity product for climate monitoring. Clim. Past Discuss., 8, 5133-5180, doi:10.5194/cpd-8-5133-2012

WMO (2008): Guide to Meteorological Instruments and Methods of Observation. World Meteorological Organization, WMO-No.8 edition.

Wypych, A., (2010): Twentieth century variability of surface humidity as the climate change indicator in Kraków (Southern Poland). Theor Appl Climatol, 101:475-482.

Xoplaki, E., González-Rouco, J.F., Luterbacher, J., Wanner, H. (2004): Wet season Mediterranean precipitation variability: Influence of large-scale dynamics and trends. Climate Dynamics 23: 63-78.

$\mathrm{Xu}$, Ch-Yu, Lebing Gong, Tong Jiang, Deliang Chen, V.P. Singh (2006): Analysis of spatial distribution and temporal trend of reference evapotranspiration and pan evaporation in Changjiang (Yangtze River) catchment. Journal of Hydrology, 327: 81- 93

Zhang, R., Alexei Khalizov, Lin Wang, Min Hu, and Wen Xu (2012): Nucleation and Growth of Nanoparticles in the Atmosphere. Chem. Rev. 112, 1957-2011. 


\begin{tabular}{|c|c|c|c|c|c|}
\hline & & $\begin{array}{l}\text { Positive } \\
\text { (sig.) }\end{array}$ & $\begin{array}{l}\text { Positive } \\
\text { (No sig.) }\end{array}$ & $\begin{array}{l}\text { Negative } \\
\text { (No sig.) }\end{array}$ & $\begin{array}{l}\text { Negative } \\
\text { (sig.) }\end{array}$ \\
\hline \multirow{5}{*}{ 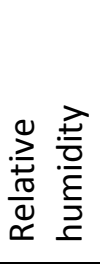 } & Winter & 0 & 4 & 25 & 21 \\
\hline & Spring & 0 & 0 & 21 & 29 \\
\hline & Summer & 0 & 0 & 4 & 46 \\
\hline & Autumn & 0 & 1 & 18 & 31 \\
\hline & Annual & 0 & 0 & 4 & 46 \\
\hline \multirow{5}{*}{ 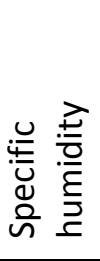 } & Winter & 1 & 42 & 7 & 0 \\
\hline & Spring & 22 & 24 & 3 & 1 \\
\hline & Summer & 6 & 17 & 23 & 4 \\
\hline & Autumn & 0 & 23 & 26 & 1 \\
\hline & Annual & 12 & 23 & 14 & 1 \\
\hline \multirow{5}{*}{ 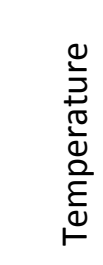 } & Winter & 25 & 25 & 0 & 0 \\
\hline & Spring & 50 & 0 & 0 & 0 \\
\hline & Summer & 50 & 0 & 0 & 0 \\
\hline & Autumn & 35 & 15 & 0 & 0 \\
\hline & Annual & 50 & 0 & 0 & 0 \\
\hline
\end{tabular}

838 Table 1: Number of stations having positive and negative trends in seasonal and annual relative and specific 839 humidity, and temperature (1961-2011).

840

841

842

843

844

845

846

847

848

849

850

851

852

853 


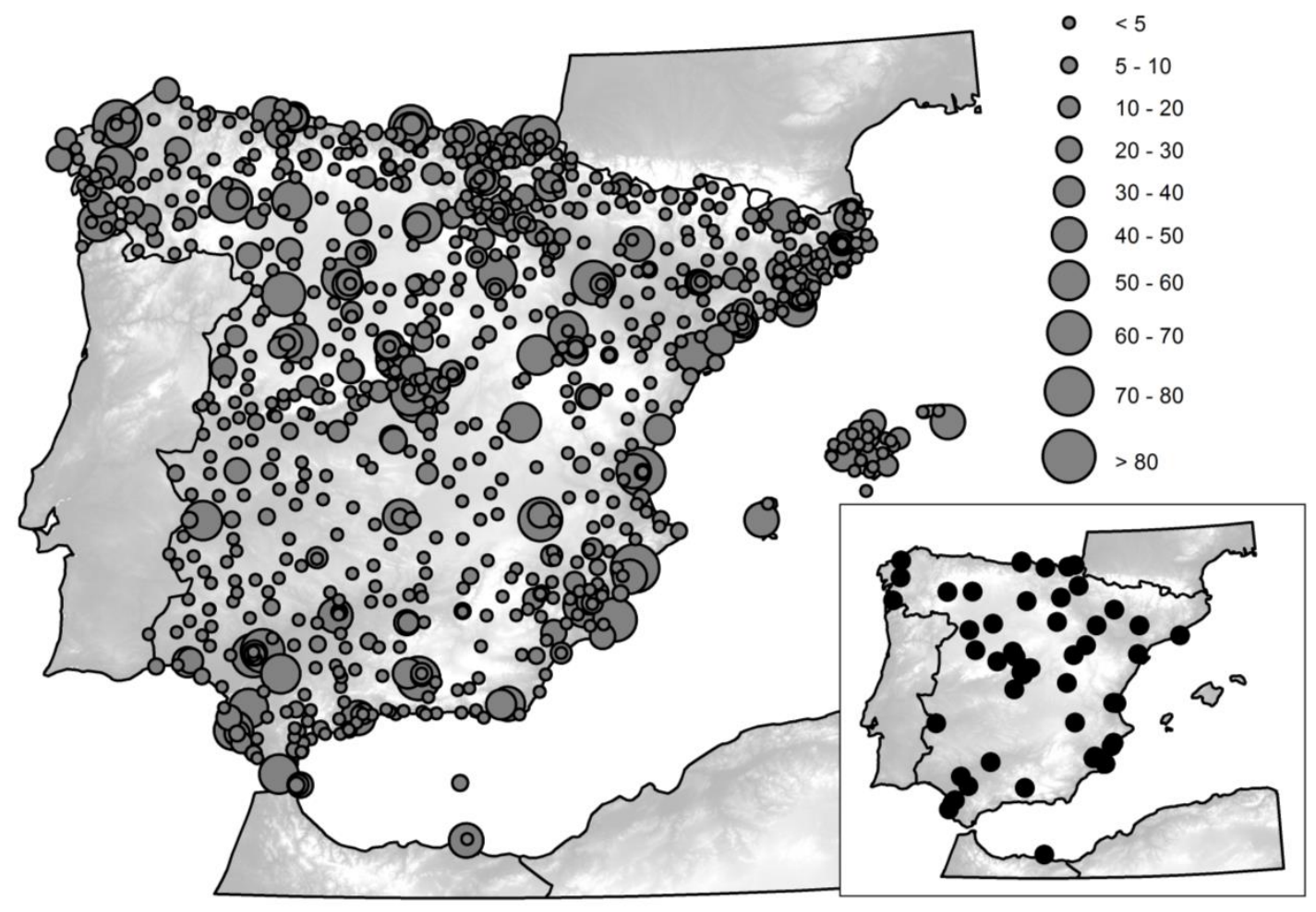

858 Figure 1: Spatial distribution of the stations measuring RH in Spain. The symbol size indicates the number of 859 years with complete data (see legend). The small map shows the spatial distribution of the 50 860 reconstructed and homogenized series of $\mathrm{RH}$ used in this study, for the period 1961-2011. 

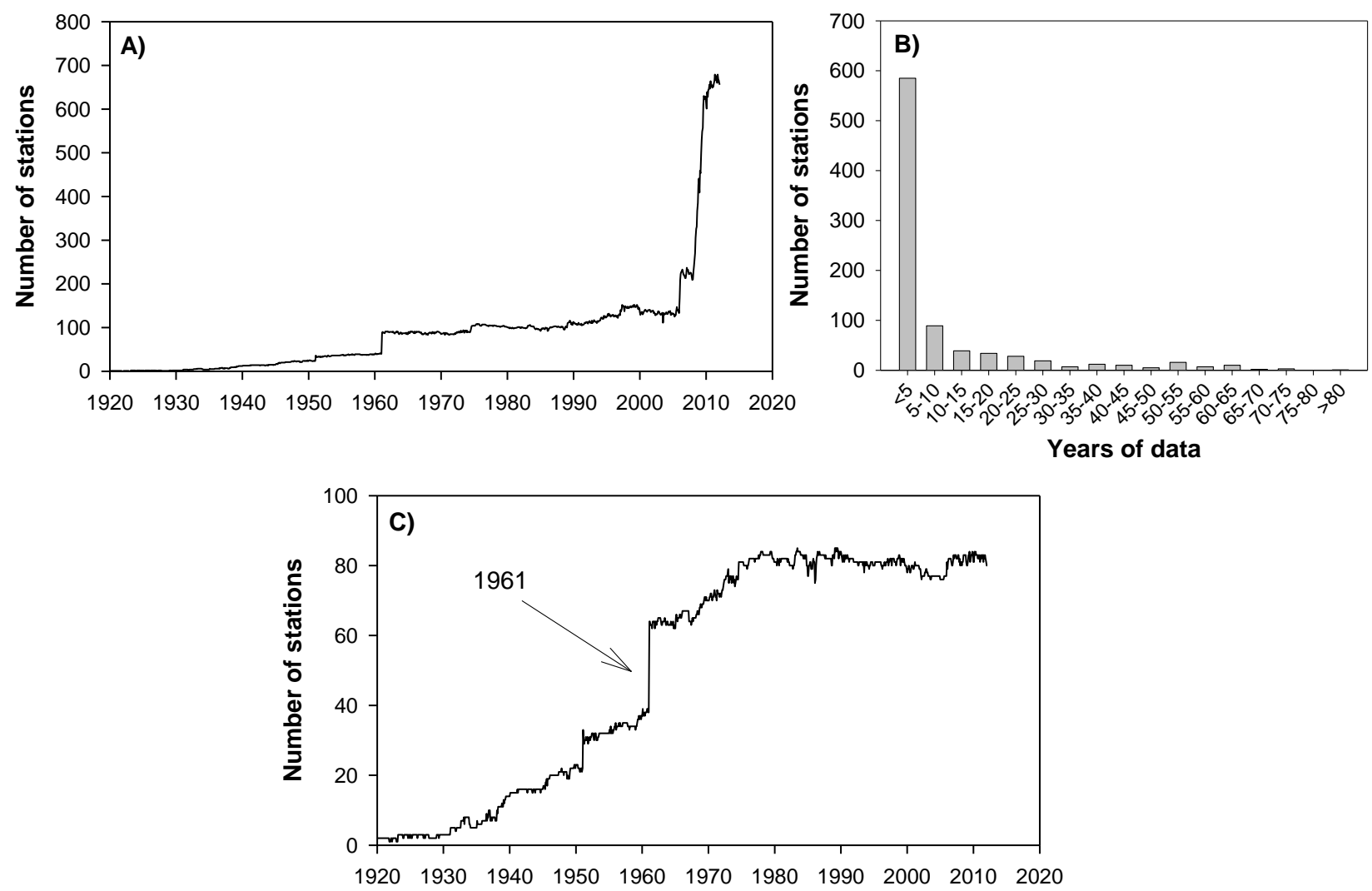

863

864 Figure 2: A) Evolution of the number of stations measuring RH (1920-2011). B) Absolute frequencies of the 865 station data length. C) Evolution of the number of stations following the reconstruction process. 

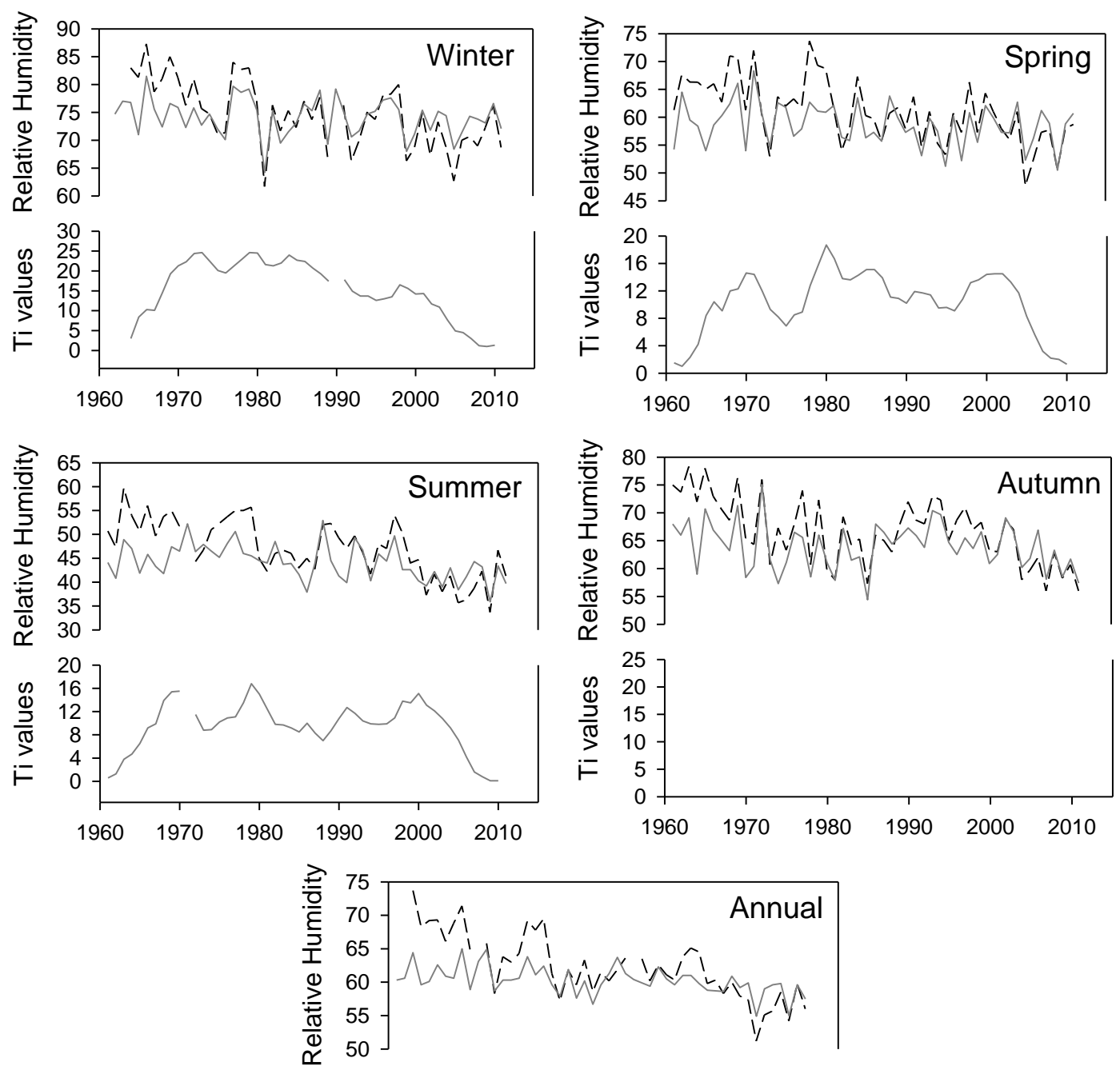

868 Figure 3: Example of data inhomogeneity, identified for 1981 for the Cuenca station (8096). The dashed line 869 indicates the candidate series, and the gray line the reference series. For each series the Ti statistic of the 870 Alexandersson test is also shown. 

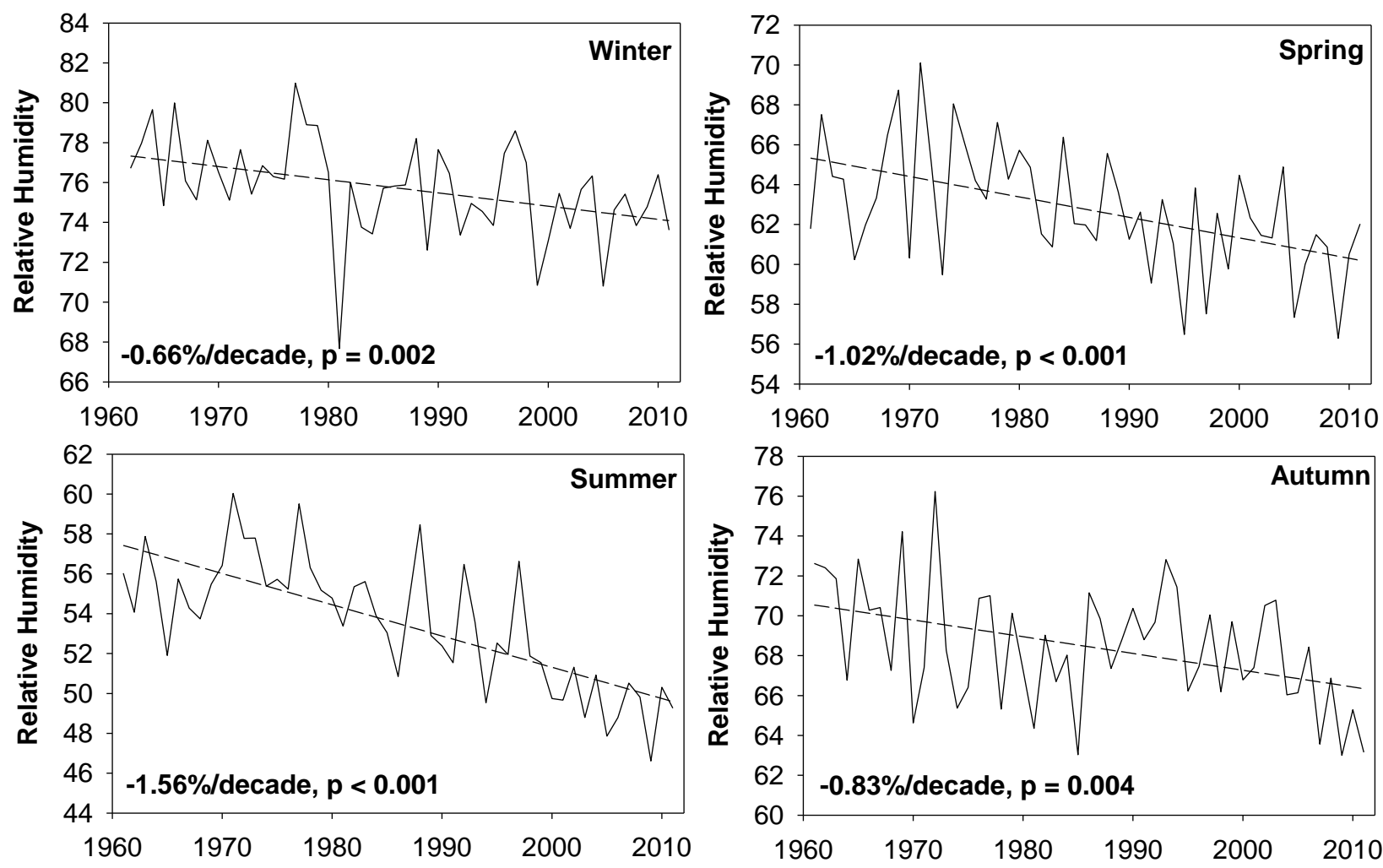

872

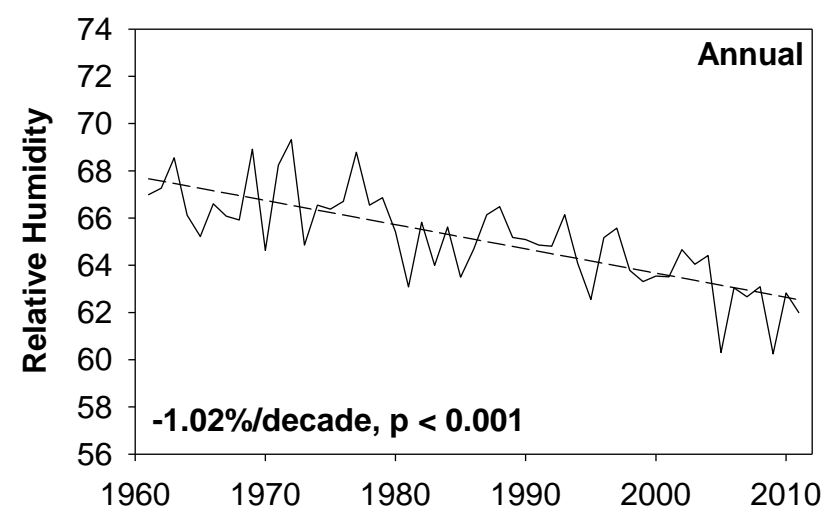

873 Figure 4: Evolution of RH in Spain, based on a weighted regional series (1961-2011).

874 

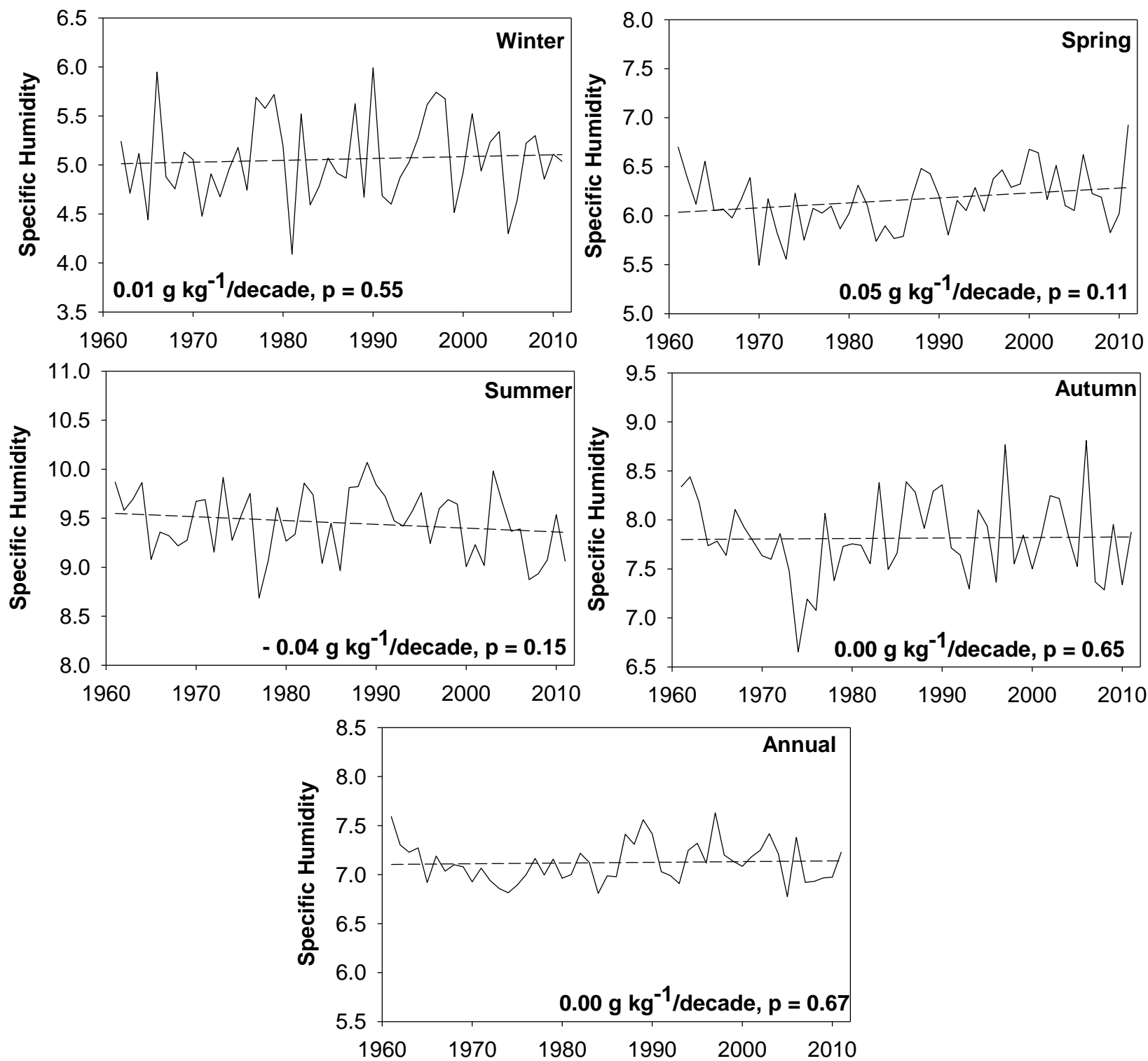

876

Figure 5: Evolution of specific humidity in Spain, based on a weighted regional series (1961-2011). 

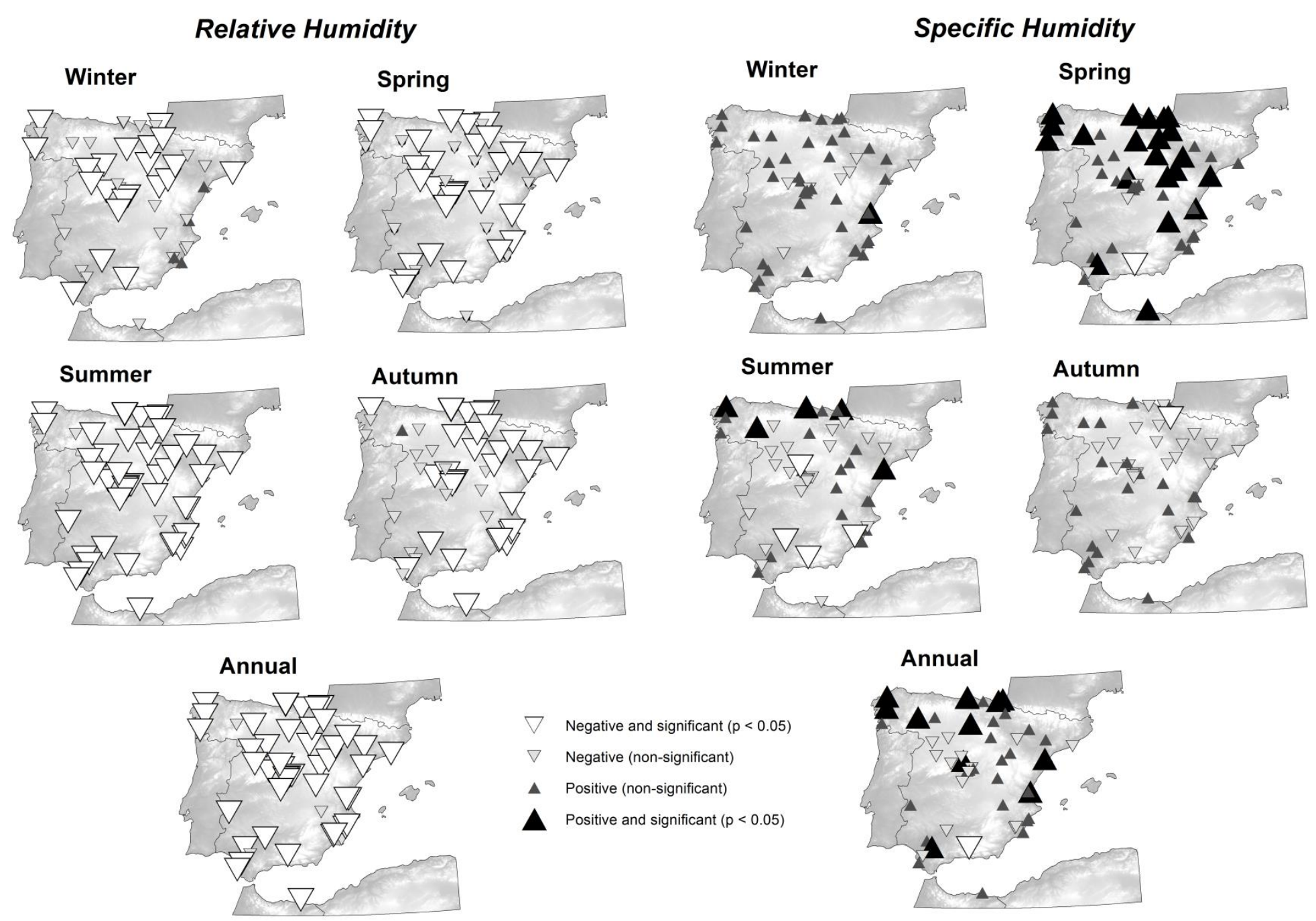

879 Figure 6: Spatial distribution of seasonal and annual trends in relative and specific humidity in Spain (1961-2011). 

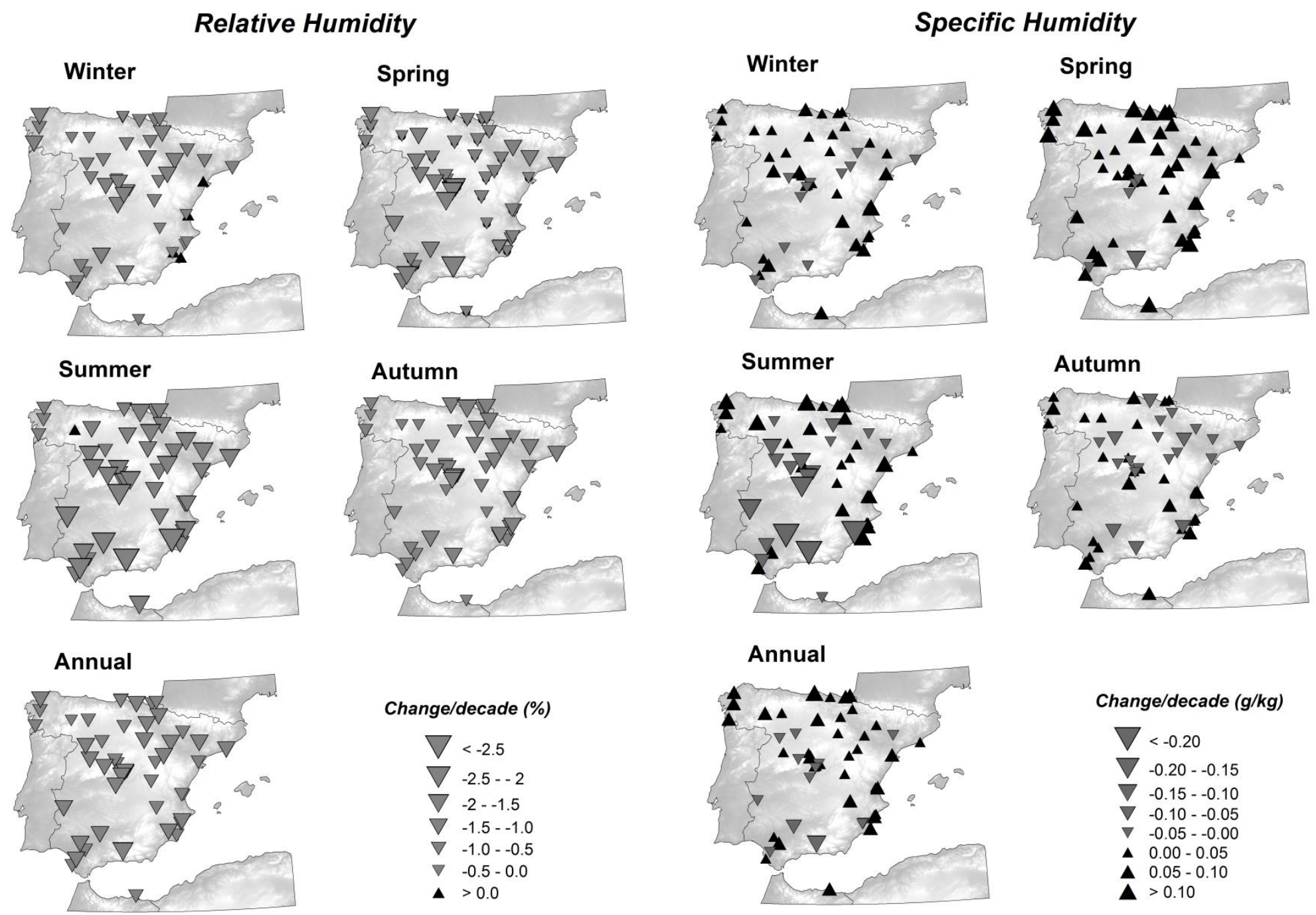
Change/decade (g/kg)
$\nabla<-0.20$
$\nabla-0.20--0.15$
$\nabla-0.15--0.10$
$\nabla \quad-0.10--0.05$
$\nabla \quad-0.05-0.00$
$0.00-0.05$
$\boldsymbol{\Delta} 0.10$.

882 Figure 7: Spatial distribution of seasonal and annual changes in the magnitude of relative and specific humidity in Spain (1961-2011). 

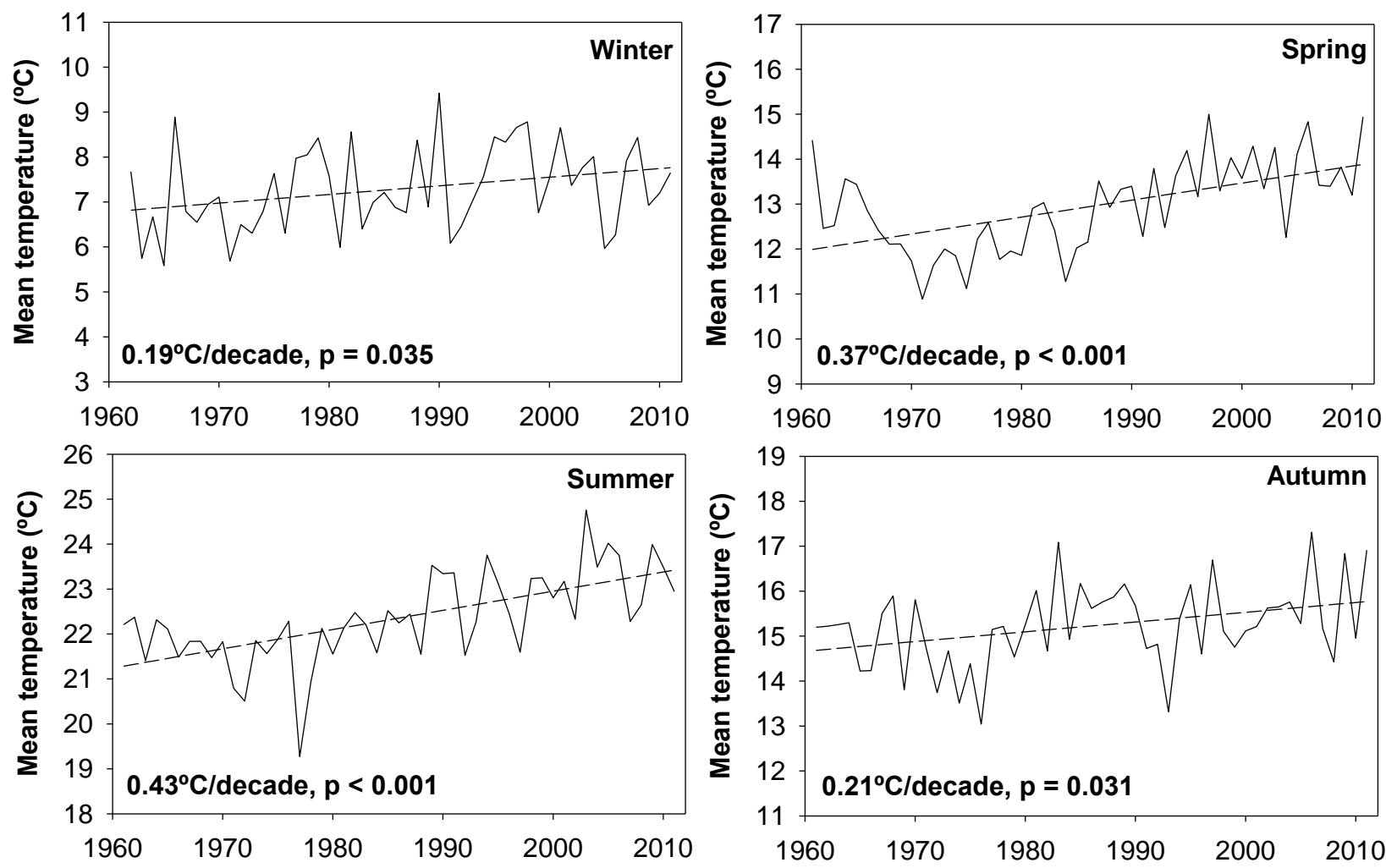

883

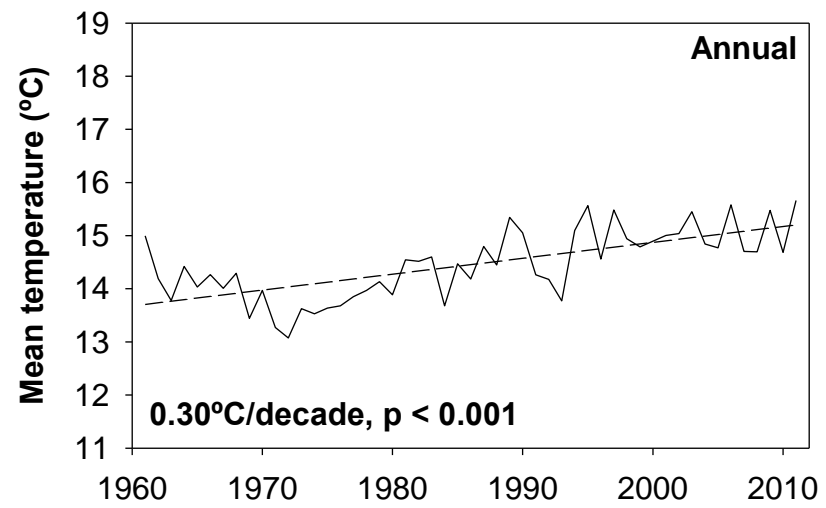

884 Figure 8: Evolution of seasonal and annual mean temperature in Spain, based on a weighted regional series 885 (1961-2011).

886

887 

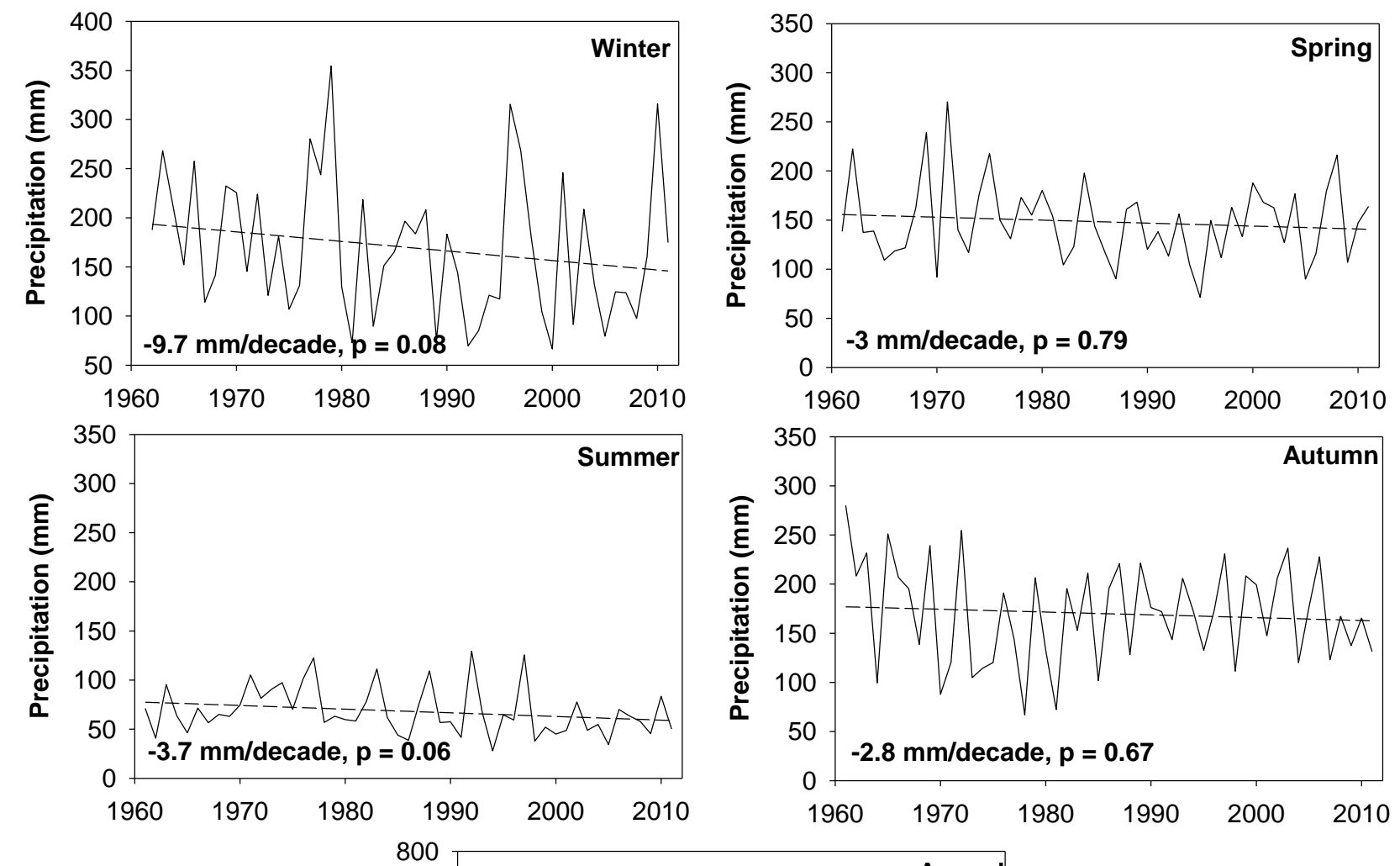

888

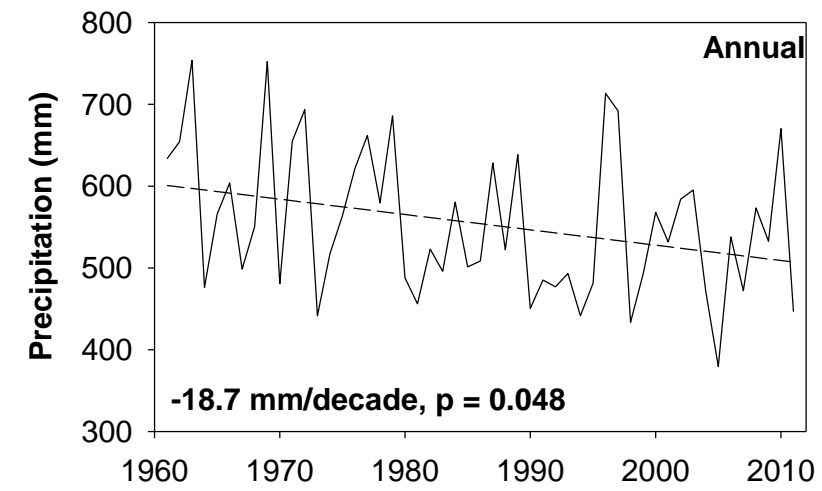

889 Figure 9: Evolution of seasonal and precipitation in Spain, based on a weighted regional series (1961-2011). 890 

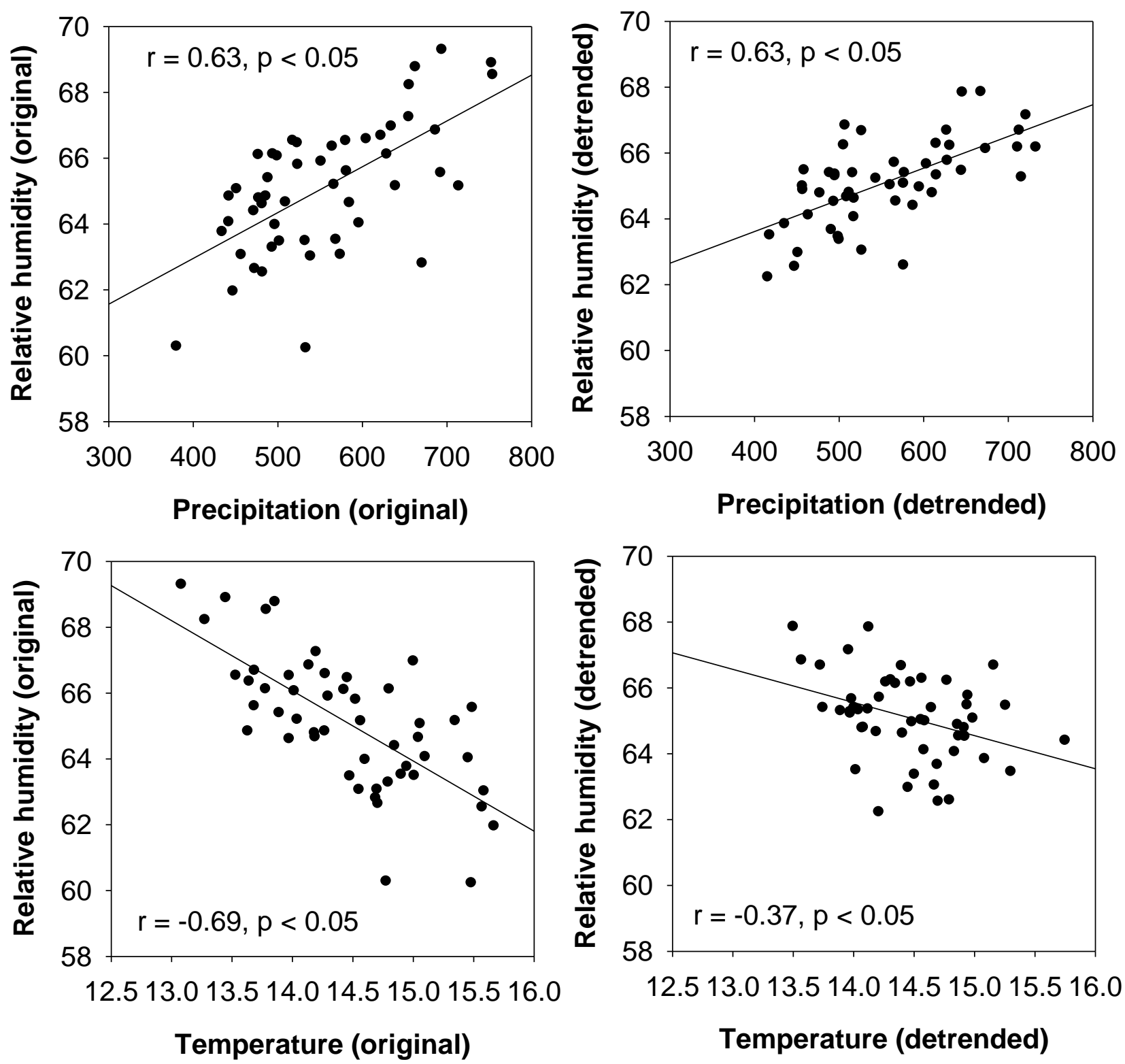

893 Figure 10: Relationship between the series of annual precipitation, temperature and RH in the regional series for Spain. Left: original series. Right: de-trended series. 

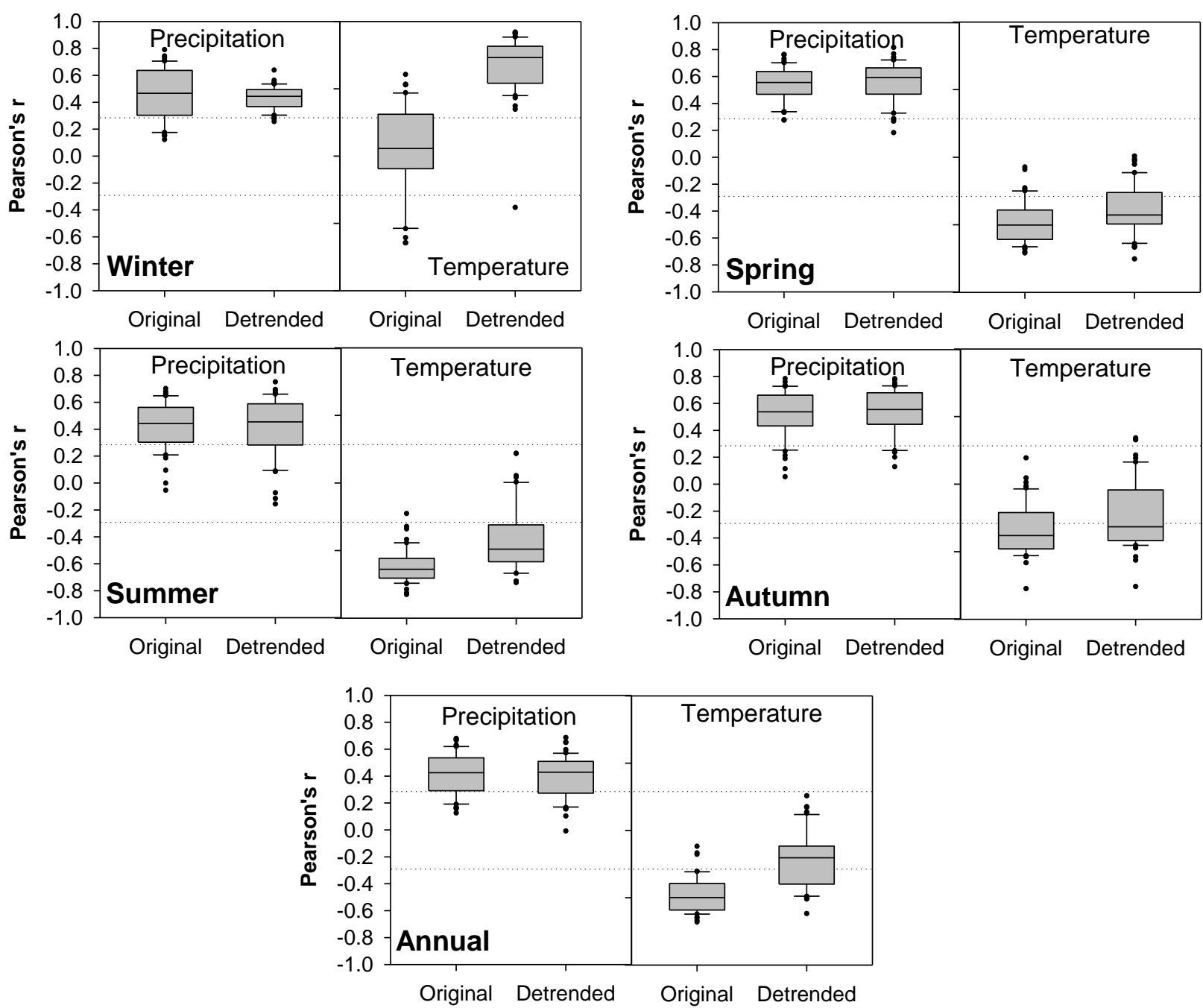

897 Figure 11: Box plots showing correlations between temperature, precipitation and RH for the 50 stations, 898 analyzed with respect to the original and de-trended series for the period 1961-2011. Dotted lines indicate 899 significant correlations $(p<0.05)$. 

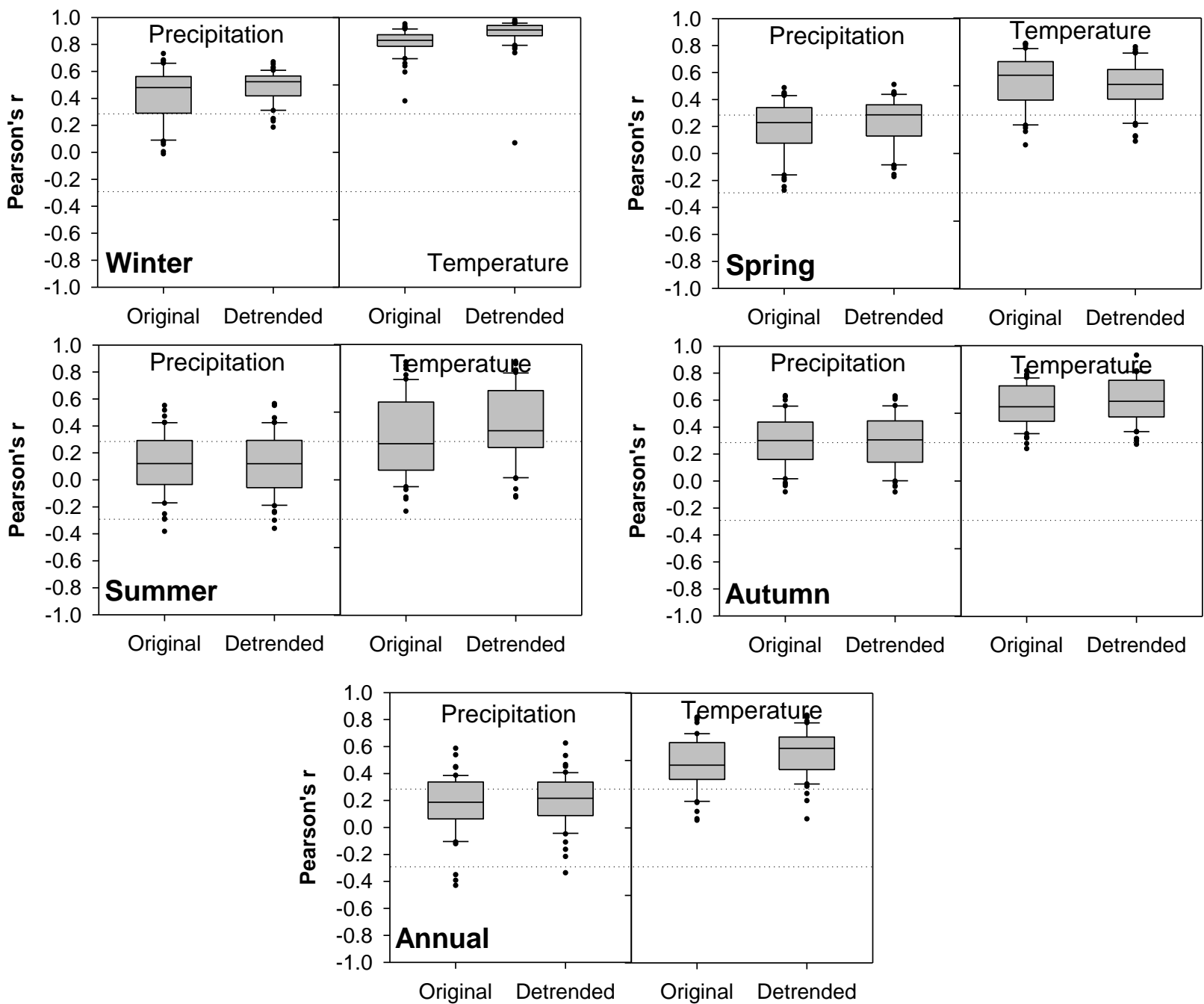

903 Figure 12: Box plots showing correlations between temperature, precipitation and $q$ for the 50 stations, 904 analyzed with respect to the original and de-trended series for the period 1961-2011. Dotted lines indicate 905 significant correlations $(p<0.05)$. 


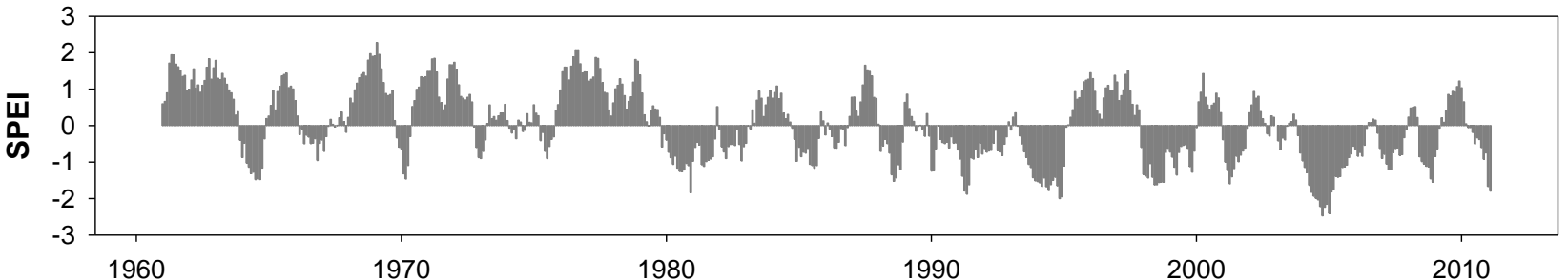

909 Figure 13: Evolution of the 12-month SPEI in Spain.

910 

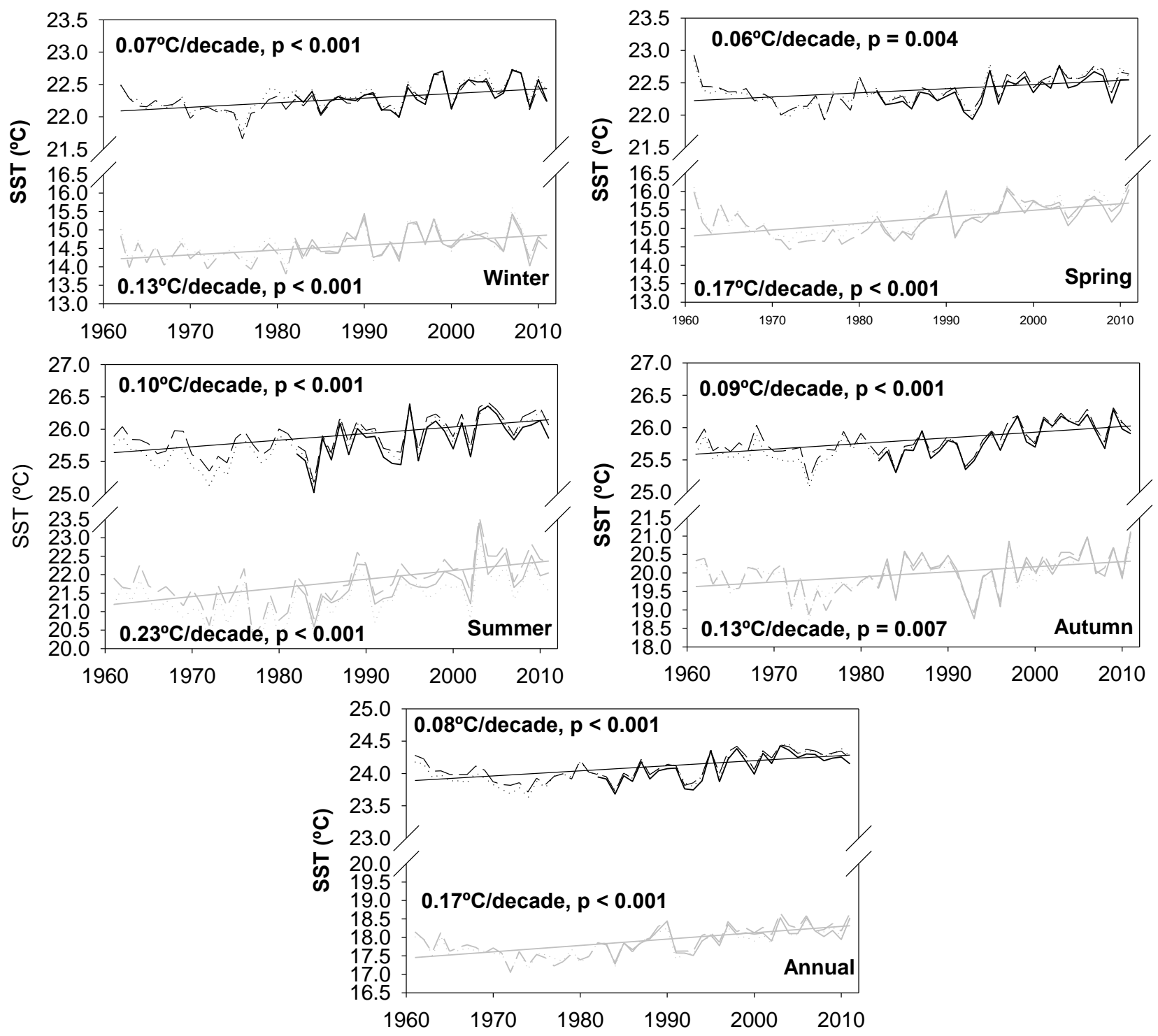

912 Figure 14: Evolution of the sea surface temperature in areas 1 (the tropical-subtropical North Atlantic 913 corridor; shown in black) and 2 (surrounding Spain; shown in gray). Solid: HadISST dataset. Dotted: 914 ERSST.v3b. Dashed: NOAA-AVHRR satellite. 

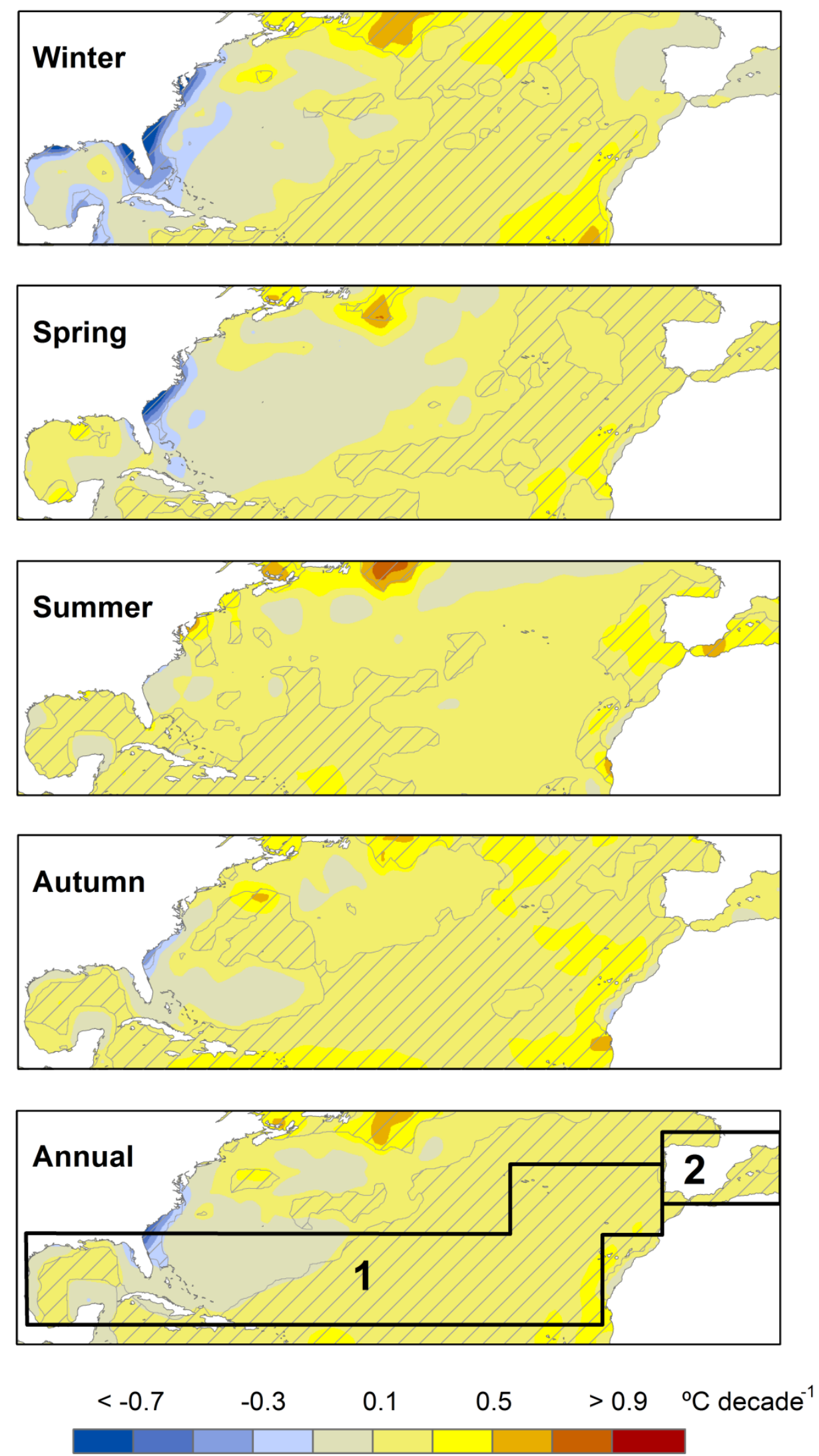

917 Figure 15: Evolution of the sea surface temperature between 1981 and 2011, based on the NOAA-AVHRR 918 dataset. The changes were determined using least square regression analysis. Lines frame areas having 919 significant trends, according to the Mann Kendall tau statistic. 